\title{
NATIONAL SECURITY AND THE FUTURE \\ JOURNAL CONTRIBUTORS \\ FROM 2000. TO 2019.
}

\author{
Prepared by \\ Đilda Pečarić ${ }^{1}$
}

\section{Introductory note}

The first issue of the National Security and The Future journal was published in 2000. In the first 20 years of journal, 134 authors published 257 papers. In this paper we provide an alphabetical overview of the authors and their biographical information. The authors' biographical information is published in its original form as it was published in the journal. The information about the authors is published in the language (English or Croatian) used for the publication of

1 Doc. dr. sc. Đilda Pečarić - Assistant Professor (external associate) in Information Science at the Croatian Catholic University (2017 to present). Assistant / Senior Assistant in Information Sciences at Faculty of Humanities and Social Sciences, University of Zagreb (2006-2016). She has published over 60 papers and a book. The main areas of reserch are: bibliometrics, visual presentation and research methods. 
their paper in the journal. Biographical information is not updated and it refers to the year in which the papers were published. The author's information also includes information on the issue number or numbers of the journal in which the author's papers were published. Only the author's name and the issue number or numbers in which the author published their papers are given for the papers that do not include the biographical information of the author.

\section{Alphabetical review of the author from vol. 1 , no. 1 (2000) to vol. 19, no. 3 (2018)}

Anna Abelmann, is a research associate and a Ph.D. candidate of the Ruhr University of Bochum, Germany, Executive Director of the International Intelligence History Association and Journal of Mediterranean and Balkan Intelligence Editorial Board member. Her doctoral thesis deals with the work of German political foundations in Israel. She specializes in German relations in Israel and the Middle East since 1945, Intelligence and Security Studies and transatlantic security cooperation after World War Two.

Paper is published in: Vol. 17 No. 1-2, 2016.

Prof. dr. sc. Wilhelm Agrell, is associate professor of history at the University of Lund (Sweden) and lecturer and consultant on intelligence analysis. He has written a number of works on security policy and the history and science of intelligence.

Paper is published in: Vol. 1 No. 2, 2000. 
Dr. sc. Gordan Akrap, St. George Association, Zagreb, (b. 1966) graduated on Zagreb Faculty of electronics and computing in 1994. In 2011 he received a PhD at the University of Zagreb, in the field of Information and Communication sciences. The title of his PhD was "Informational strategies and operations in public knowledge shaping". He had an active role in Homeland war. During his career in diplomatic and security structures of Croatia he completed a number of professional courses, including Diplomatic Academy. He is active in research of national and regional security, intelligence and history of Homeland War. He published a number of books, and papers in journals and proceedings.

Papers are published in: Vol. 10 No. 2, 2009; Vol. 11 No. 4, 2010; Vol. 12 No. 1-2, 2011; Vol. 14 No. 2, 2013; Vol. 16 No. 2-3, 2015; Vol. 17 No. 1-2, 2016; Vol. 17 No. 3, 2016; Vol. 18 No. 1-2, 2017; Vol. 19 No. 1-2, 2018.

Kenneth Allard, Senior Associate, International Security Program. Expertise: Regional security issues: Western Europe, Iraq, Bosnia, Somalia; intelligence, information warfare, commercial information assurance; defense technology, management, organization, and procurement reform; international peacekeeping; UN reform; NATO expansion. A former army colonel, Kenneth Allard is a well-known commentator on international security issues and is featured as a military analyst with MSNBC and NBC News. His military career as an operational intelligence officer also included service on the faculty of the United States Military Academy, as special assistant to the Army Chief of Staff, and as dean of students at the National War College. A 
command and control expert, he served in 1996 on special assignment with the U.S. 1st Armored Division in Bosnia. He also played key roles in two of the most significant reform efforts in Pentagon history: as a congressional fellow, helping to draft the landmark 1986 GoldwaterNichols Act; and directing the study that produced the sweeping procurement reforms of the 1994 Federal Acquisition Streamlining Act. A noted author and lecturer, Allard's many publications include two books, Somalia Operations: Lessons Learned (National Defense University Press, 1995) and Command, Control and the Common Defense (Yale University Press, 1990), which won the 1991 National Security Book Award. Allard holds a Ph.D. from the Fletcher School of Law and Diplomacy, an M.P.A. from Harvard University, and he is an adjunct professor in the National Security Studies Program, Georgetown University.

Paper is published in: Vol. 2 No. 1-2, 2001.

Lt. General (retd.) Ioannis Anastasakis, is an Air Force Academy (Greece) graduate who retired as Lieutenant General-Air Force pilot. He is RIEAS International Advisor and founder of the Regional Observatory for Security and Economic Development (ROSED). He was designated "Expert Group" Chairman to the multinational Wassenaar Arrangement, which deals with export controls of military and advanced technology goods and technologies. $\mathrm{He}$ was also member of the Greek Ministry of Foreign Affairs' International Sanctions Monitoring Working Group. Lieutenant General (ret.) Anastasakis is experienced in MoD international and bilateral relations, with specialty in security, cooperation, procurement, 
defense investment and armaments. He was previously posted to NATO/SHAPE staff in Belgium as "Reaction Forces Exercise Planner". Periodically he performs as a guest speaker in institutions, military and diplomatic academies, staff colleges, C-5 and RIEAS courses. He is author of two books titled: "Asymmetric Threats and Controlled Items" and "Controlled Items of Military Significance: Case Studies".

Papers are published in: Vol. 17 No. 1-2, 2016; Vol. 18 No. 1-2, 2017.

Duje Ančić, rođen je u Splitu 1980. godine. Diplomirao je 2004. godine na Sveučilišnom studiju kriminalistike, Sveučilišta u Zagrebu te godinu kasnije 2005. na Pravnom fakultetu Sveučilišta u Splitu. 2009. godine položio je pravosudni ispit, a 2016. godine završio je Ratnu školu "Ban Josip Jelačić". Posljednja je godina poslijediplomskog doktorskog studija Informacijskih znanosti, smjer Društveno humanistička informatika pri Filozofskom fakultetu. Od 2006. godine radi u Ministarstvu vanjskih i europskih poslova u kojemu obnaša različite funkcije i nastavlja se znanstveno i profesionalno usavršavati pohađajući brojne seminare, radionice te sudjelujući u radu nekoliko odbor

Paper is published in: Vol. 16 No. 2-3, 2015.

Dr. sc. Mladen Ančić, rođen 1959 u Sarajevu (BiH). Radi u Zavodu za povijesne znanosti HAZU u Zadru, i predaje na Hrvatskim studijima Sveučilišta u Zagrebu.

Paper is published in: Vol. 6 No. 3-4, 2005. 
Mr. sc. Natalia Anić, magistrirala je 2010. na smjeru Marketing na Ekonomskom Fakultetu u Zagrebu, te je 2011. upisala Doktorski studij informacijskih i komunikacijskih znanosti. Zaposlena je na području marketinga i razvoja u bankarskom sektoru. Predaje Marketing financijskih institucija na privatnoj visokoj poslovnoj školi.

Paper is published in: Vol. 13 No. 3, 2012.

Dr. sc. Ian Anthony, Project Leader, SIPRI Export Controls in Europe Project. Ian Anthony (UK) received his doctorate from the University of London in 1991. The title of his thesis was The international arms trade: Case studies of India and Pakistan 1947-86. From 1993 to $1998 \mathrm{Dr}$ Anthony was leader of the SIPRI Arms Transfer Project. He is currently leading a project to develop an internet database on export control. In addition to many articles in journals and edited volumes, Dr Anthony is the author of three monographs: Warsaw Pact Military Expenditure, (Jane's Publishing Group: London 1988) with Jonathon Eyal; the Naval Arms Trade, (Oxford University Press: Oxford, 1989); and Arms Trade and Medium Powers: Case studies of India and Pakistan 1947-90, (Simon \& Schuster: Brighton 1991). He is the editor of four volumes: Arms Export Regulations (editor), (Oxford University Press: Oxford 1991), The Future of the Defence Industries of Central and Eastern Europe, (Oxford University Press, Oxford 1994), Russia and the Arms Trade, (Oxford University Press: Oxford 1988) and A Future Arms Control Agenda, (Oxford University Press: Oxford 2001).

Paper is published in: Vol. 2 No. 1-2, 2001. 
Dr. sc. Joško Badžim, pri uredu Vijeća za nacionalnu sigurnost $\mathrm{RH}$ u Zagrebu.

Paper is published in: Vol. 14 No. 1, 2013.

Prof. dr. sc. Jordan Anguelov Baev (b. 1954, Sofia), Associate Professor of contemporary history, national security, crisis management at the New Bulgarian University, Sofia. Since 1999, Executive Director, Center for Conflict Studies, Sofia. International academic activity: Central European University, Budapest; The George Washington University, Washington DC; King's College, London; Helsinki University; American University; Blagoevgrad; U.S. Institute of Peace \& Black Sea University Foundation, Sinaia, Romania; "George C. Marshall" Center for European Security. Participation in International Conferences: Amsterdam, Athens, Berlin, Bratislava, Brno, Budapest, College Park, Maryland, Graz, Leipzig, London, Managua, Moscow, Prague, Reykjavik, Stanford, California, Warsaw, Washington, D.C. Publications: 142 publications on contemporary history, foreign policy, international relations and conflict studies, and four books, among them: Military-Political Conflicts after World War II and Bulgaria. Sofia 1995, and Greek Civil War: International Dimensions. Athens 1997. Co-author/co-editor/ of 12 books.

Paper is published in: Vol. 1 No. 1, 2000.

Dr. sc. Ivan Bagarić (b. 1941, Tomislavgrad, Bosnia and Herzegovina). Specialized in public health; Assistant at the Medical Faculty, University of Mostar; Assistant Minister of Health in the Federation of Bosnia and Hercegovina. Head of the Medical Headquarters for the HVO during 
the war, with the rank of Major-General. Elected twice to the Parliament of Bosnia and Hercegovina.

Paper is published in: Vol. 1 No. 2, 2000.

Gintaras Bagdonas, In 1991 he graduated from Kaunas University of Technology, Faculty of Energetics with an engineering sciences degree. Between 2004 and 2006 he studied at the Institute of International Relations and Diplomacy at Vilnius University and holds an MA in Political Sciences. In 2002 Col. Bagdonas completed the strategic senior officer course at NATO Defence College, Rome, Italy. Career: Col. Bagdonas was appointed as Director of NATO Energy Security Centre of Excellence (NATO ENSEC COE) based in Vilnius, Lithuania in August 2014. Prior to this appointment he had a two-year assignment as Minister Counsellor and Head of the Special Mission of the Republic of Lithuania to the Islamic Republic of Afghanistan in Kabul under the subordination of the Ministry of Foreign Affairs of the Republic of Lithuania. Before this appointment he served as Commandant of the General Jonas Zemaitis Military Academy of Lithuania; Director of Intelligence of the EU Military Staff, (interim Brigadier General Rank) in Brussels, Belgium; Director of the Second Investigation Department (Military Intelligence and Security) under the Ministry of National Defense of the Republic of Lithuania. From 1995 to 1998 he served as Defense Attaché of the Republic of Lithuania to the Republics of Latvia and Estonia. Col. Bagdonas has published several articles on different aspects of strategic partnership and international relations. He has also given lectures on "Intelligence and State" for the Military Diplomacy Master Students at 
the Military Academy of Lithuania. Besides native Lithuanian language, Col. Bagdonas speaks English and Russian and has acquired basic knowledge of French and Persian. His interests and hobbies include mountaineering, cycling, professional and historical literature.

Paper is published in: Vol. 17 No. 1-2, 2016.

Tomislav Bajs, ENCONET, Zagreb, Croatia.

Paper is published in: Vol. 17 No. 1-2, 2016.

Anastazija Bakran, Ured za upravljanje u hitnim situacijama, Zagreb, Hrvatska.

Papers are published in: Vol. 18 No. 1-2, 2017; Vol. 19 No. 1-2, 2018.

Gordan N. Bardos, is Assistant Director of the Harriman Institute, Columbia University. A specialist on Southeastern Europe, he has written extensively on various aspects of the crisis in the former Yugoslavia. Mr. Bardos also serves as Executive Director of the Association for the Study of Nationalities (ASN), the world's largest scholarly organization devoted to the study of problems of nationalism and ethnic conflict in the post-communist world. Since 1998, he has also worked as a Balkans consultant for Freedom House. In 1996-97, he worked in Bosnia-Herzegovina as a political advisor to the U.S. military. Primary research interests include problems of democracy in a multinational environment, comparative state and nation building processes, and the role of Islamic fundamentalist groups in Southeastern Europe.

Paper is published in: Vol. 3 No. 1-2, 2002. 
General pukovnik dr. sc. Slavko Barić, rođ. 27. travnja 1957., u Bocanjevci - Belišće, zamjenik je načelnika Glavnog stožera Oružanih snaga Republike Hrvatske za planove i resurse. U OS RH obnašao je sljedeće dužnosti: 1991./92. zapovjednik 107. brigade; 1992./93.

zapovjednik 132. brigade; 1993./95. - zamjenik zapovjednika Zbornog područja Osijek; 1995./96. - pročelnik Vojnog kabineta u Uredu Predsjednika $\mathrm{RH}$; 1996./97. - zamjenik zapovjednika Zbornog područja Osijek; 1997./99. - vojni izaslanik Predsjednika Republike Hrvatske za mirnu reintegraciju; 1999./2001. - zamjenik zapovjednika Ratne škole "B. J. Jelačić"; 2001./03. - zapovjednik Zbornog područja Osijek; od 2003. - zamjenik N GS OSRH. Trenutno obnaša dužnost zapovjednika Hrvatskog vojno učilišta "dr. Franjo Tuđman". Na Fakultetu političkih znanosti Sveučilišta u Zagrebu obranio je 2010. doktorsku disertaciju na temu „Asimetrično ratovanje i transformacija vojne organizacije: Adaptacija vojnih doktrina i metoda djelovanja u odgovoru na asimetrične ugroze“.

Paper is published in: Vol. 11 No. 4, 2010.

Prof. dr. sc. Tome Batkovski (b.1952, Ohrid, Macedonia) Professor at the Faculty of Security in Skopje. In his scientific work deals mainly with (a) research of national security in general and security questions related to Republic of Macedonia and the Balkan region in specific; (b) criminal investigation in the area of criminal acts against the state; (c) research in the area of organized crime. Dr. Batkovski is author of over thirty articles. His book The Plot of the Albanian Nationalism in Macedonia (Skopje; 1994) treats from a criminological aspect the phenomenology of illegal organization and 
activities based on extreme Albanian nationalism in Macedonia from 1945-1987.

Paper is published in: Vol. 1 No. 1, 2000.

Dr. sc. Goran Belamarić, doctoral thesis (2015): Model for ship protection against Piracy attacks, Faculty of Maritime Studies, University of Rijeka.

Paper is published in: Vol. 19 No. 1-2, 2018.

Maj. gen. Carlo Bellinzona, Born September 18, 1941. From October 1998 Director of CeMiSS, Centro Militare di Studi Strategici, Rome, Italy. From July 1996 - October 1998 National Military Representative at SHAPE; from 1993-1996 COS of the 3rd Corp in Milan; from 1991-1993 Commanded the Garibaldi Bresaglieri Brigade. Qualifications: Degree in Political Science from Bologna University; Post-graduate degree in European Studies, at De Gasperi Institute in Rome; Degree in Strategic Sciences at Turin University. He has focussed extensively on History and International Relations and is author of works in these fields. He is a lecturer on political-strategic issues at several Italian universities (Milan - Florence - Teramo Palermo - Cassino).

Paper is published in: Vol. 2 No. 1-2, 2001.

Ivan Bilić, rođen 1964. u Sinju, diplomirani ekonomist, sudionik Domovinskog rata od kraja 1990. zbog čega je više puta odlikovan. Tijekom 2001, odlazi na rad $u$ inozemstvo gdje u privatnoj tvrtki radi na različitim razvojnim projektima.

Paper is published in: Vol. 6 No. 1-2, 2005. 
Helene L. Boatner ( $\dagger$ 2000) Served with the Central Intelligence Agency from 1963 until 1996. Employed for ten years as an analyst with the Office of Economic Research in the Directorate of Intelligence, and with the Office of National Estimates. Later served in a wide variety of executive positions, including Director of Political Analysis, Director of Leadership Analysis, Director of Current Production and Analytic Support and Comptroller. Spent two years in the U. S. Mission to the United Nations. Also served on the Editorial Board of CIA's Studies in Intelligence and was Chairman of that Board for many years. Received a B. A. in Mathematics from the University of Texas and a M.A. in Economics from The American University, and was a graduate of the National War College in Washington, D.C. Helene Boatner died on 9 January 2000.

Paper is published in: Vol. 1 No. 1, 2000.

Lt. Gen. László Botz (b. 1944, Pestújhely, Hungary). Military education at the Military Academy (1966), War College (1980) and General Staff Course (1983). From 1969 to 1991, held various military positions, including Head of Division, Intelligence Division, and Deputy Director of Military Intelligence. From 1991 to 1995, held positions at the Ministry of Defense, including the Head of the Department of International Relations and Security Policy, Representative of Ministry of Defense, and the Hungarian Home Defense Forces at the Hungarian NATO Mission, Brussels. In 1995, appointed Director General of MIO. His foreign services include missions to the Republic of Vietnam (1973), United States (Assistant Military Attaché, 19761979), Italy (Defense Attaché, 1985-1990) and 
Belgium (Military Representative,1993-1995). $\mathrm{He}$ is married, with two grown-up children.

Paper is published in: Vol. 1 No. 2, 2000.

Gen. Todor K. Boyadjiev (b. 1939, Bulgaria). President of the Bulgarian Euro- Atlantic Intelligence Forum, Adjunct Professor in National Security and Intelligence at the universities of Sofia, Veliko Tarnovo and Bourges, and Official Senior Consultant to the Bulgarian National Television on national security matters. Studied at the University of Technology, Sofia, and has a Major in Electronics and Telecommunications. From 1967 to 1972, Deputy Commercial Counselor of Bulgaria to the United States. Elected member of IEEE in 1969. Former advisor to the Chairman of the State Committee on Science, Technical Progress, and Higher Education; previously employed at the Ministry of Foreign Affairs (UN and Disarmament Department); former Counselor at the Permanent Mission of Bulgaria to the United Nations; former Minister Plenipotentiary and Extraordinary at the Ministry of Foreign Affairs. In November 1990, by decree of the President of Republic of Bulgaria, received the military rank of General-Major. From February 1990 until June 1992, "Executive Secretary" - Deputy Minister to the Ministry of Internal Affairs. Has headed the Information Division, International Department, Public Relations, Press Center, National Central Bureau of the I.C.P.O. INTERPOL, etc.

Paper is published in: Vol. 1 No. 2, 2000. 
General (ret.) Yair Cohen, had 32 years of Military Service in the IDF. At his last position he served as the Head of the Cyber \& Intelligence Unit.

Paper is published in: Vol. 18 No. 1-2, 2017.

Prof. dr. sc. Marc Cools, is a Professor in Criminology at the Free University of Brussels and Ghent University.

Paper is published in: Vol. 18 No. 1-2, 2017.

Francesco Cossiga (b. 1928, Sassari). Holds a law degree and was Professor of Constitutional Law at Sassari University. Active member of Catholic Action and $\mathrm{FUCl}$, and in 1945 joined the Christian Democratic Party, becoming Provincial Secretary from 1956 to 1958 and leader of the DC Group on the Sassari City Council until 1966. He served as Minister for Home Affairs in the 2nd and 4th Andreotti governments, but resigned in May 1978 following the murder of Aldo Moro. He was reelected Deputy for the sixth time on 3 June 1979 , and was the Chairman of the Chamber of Deputies Foreign Affairs Committee. On August 4, 1979 headed a coalition government of the DC, PSDI and PLI Parties, and from April 4, 1980 to October 18, 1980 headed a second DC, PSI and PRI coalition government. In 1983, as Senator for the Tempio-Orieri constituency, was elected Speaker of the Senate. On June 24, 1985, elected President of the Republic at the first ballot. Left office on April 28, 1992 and was appointed Life Senator. Named "doctor of civil law" from Oxford University, Honorary Fellow of Oriel College, Oxford, member of the Council of the Foundation of the Academy of Philosophy Studies of Lichtenstein, Honorary Senator of the Senate of the University of Bonn. 
Holds honorary degrees from major universities around the world.

Francesco Cossiga was editor of the first issue of the National Security and The Future (vol. 1 no. 1, 2000).

Paper is published in: Nacionalna sigurnost i budućnost (zbornik, svezak 1, 2001)

Grozdan Cvetkovski (b. 1956, Kriva Palanka, Macedonia). Holds B.Sc. in Faculty of Security in Skopje, and Master's Degree in International Political Relations from the Law Faculty, Skopje. Doctorate in progress: Political requirements of organized crime in post-communist countries, with a special emphasis on the conditions in the Republic of Macedonia. Worked in the Interior Ministry for many years. Former Director of the Security Faculty. Founder of the first detective agency in Macedonia. Current post: Director of Analysis in the Intelligence Agency of the Republic of Macedonia. Published works: Terrorism in the Modern World, Skopje, 1986; and What we fought for, Skopje, 1995.

Paper is published in: Vol. 1 No. 2, 2000.

Daniel Ćosić-Dragan (b. 1966, Sinj, Croatia), graduated at Faculty of Electrical Engineering and Computing in Zagreb. From August 1990 he was actively engaged in defence of the Republic of Croatia. He continued his career in Croatian security and diplomatic services. His areas of research are history of Homeland War, international terrorism and business and competitive intelligence.

Paper is published in: Vol. 9 No. 1-2, 2008. 
Dr. sc. Krešimir Ćosić (b. 1949, Zagreb, Croatia). Holds B.Sc., M.Sc. and Ph. D. degrees from University of Zagreb, Croatia. Visiting research fellow at Aerospace Department, Ann Arbor University of Michigan in 1990. Presently full professor at the Faculty of Electrical Engineering and Computer Science at the University of Zagreb, Croatia. Since 1993, President of the Military-Technical Council of the Ministry of Defense of Croatia. Also former Deputy Minister of Defense of Croatia from 1996-2000. Dr. Ćosić is at present director of the Institute for Defense Studies, Research and Development, which was established in 1999. $\mathrm{He}$ is married and has two children.

Paper is published in: Vol. 1 No. 1, 2000.

Prof. dr. sc. Nenad Debrecin, Faculty of Electrical Engineering and Computing, University of Zagreb. Born: 1953; Department of Power Systems, Member of the Croatian Academy of Engineering, (admitted 1999), B.Sc. Electrical Engineering (1975), M.Sc. Electrical Engineering (1984), Ph.D. Electrical Engineering (1997), all from the Faculty of Electrical Engineering and Computing, University of Zagreb, email: nenad.debrecin@fer.hr Heat Transfer, Nuclear Power Plants, Accident Analysis, Nuclear Power Plant Simulation, System Thermalhydraulic Codes, Uncertainty Analysis.

Paper is published in: Vol. 17 No. 1-2, 2016.

Dr. sc. Stevan Dedijer (born 1911, Sarajevo). Education: Collegio Internazionale Monte Mario, Rome, 1924 - 1929; Taft School, Watertown, Connecticut USA; BS in Theoretical Physics, Princeton University, USA, 1934; Ph. D. 
Honoris Cause, Lund University. Professional Experience: Columnist in Competitive Intelligence Review, USA, 1992 - 1994; Instructor of Intelligence and security courses, Lund University, Sweden 1974 - 1993. Consultant to the U.N., European Community, UNESCO, Saudi Arabia, Venezuela, Sweden, PLO, ex-Yugoslavia, Croatia, and OECD (organized in 1980 for the "Economic Intelligence for Development"). Fellow of Institute of Advanced Studies in Social Sciences, Palo Alto, California, 1969 - 1970. Studies in Intelligence: Dartmouth College, NSF, EXXON; corporation grants 1972 - 1975. Founder and director of Research Policy Institute, Lund University, Sweden 1966-1978. Studies in research and development policy: Niels Bohr Institute, Copenhagen, and Lund University, Sweden 1961 - 1966. Researcher, nuclear physics, Nuclear Institute of Belgrade, Tait Institute, Edinburgh, and Ruder Boskovic Institute, Zagreborn Director of Nuclear Institute, Belgrade 1952 - 1954. Journalist: Newsweek - New York, Slobodna RecPittsburgh, Borba, Tanjug, Politika - Belgrade, 1936 - 1952. Publications: Published more than 150 papers and reports in the fields of Intelligence and Security, and Science and Technology policy, including: "Swedish Technical Attaches and Innovation Intelligence", 1994; "Management and Development by Intelligence, Japan, 1860 - 1990", JS and EI, 1992; "Does IBM Know What Business it is in?", 1990, in Social and Economic Intelligence; "Elizabethan Intelligence - The Rainbow Enigma", 1986, Internet Journal of Intelligence; "Chinese Science: Ancient and Modern", cover story in Nature, August, 1975; "Why did 
Daedalus Leave", Science,1962. Publications in his honor: "The Intelligence Corporation", Jon Sigurdsson, Yael Torneurd, editors, 1992; "From Research Policy to Social Intelligence", J. Annerstedt, A. Jamison, editors, 1987; "Clio goes Spying - Essays in the History of Intelligence", W. Agrell, C. Hjort, eds. 1983. Founder of Business Intelligence - "Intelligence in the 21st Century", Conference, Priverno, Italy, 2001.

Paper is published in: Vol. 1 No. 3-4, 2000.

Gary T. Dempsey, is a foreign policy analyst at the Cato Institute in Washington, DC. He is the coauthor of the newly published book, Fool's Errands: Washington's Recent Encounters with Nation Building, and his documentary film, Collateral Damage: The Balkans after NATO's Air War, was featured in several film festivals, including the 2000 United Nations Association Human Rights Film Festival. He has three times served as an international elections supervisor in Bosnia-Herzegovina for the Organization for Security and Cooperation in Europe. His academic articles have appeared in Mediterranean Quarterly and the Southern Journal of Philosophy. Mr. Dempsey's opinion articles have been published in numerous American newspapers, including the Journal of Commerce and the Washington Times, and in regional newspapers such as Danas in Yugoslavia, Exoysia in Greece, and Sega in Bulgaria. Mr. Dempsey received his undergraduate degree in international relations from Rutgers University in 1991 and his master's degree from the College of William \& Mary in 1995.

Paper is published in: Vol. 2 No. 1-2, 2001. 
Wilhelm Dietl (born 1955 in Bad Koetzting), is a well-knownn German journalist and expert for Near and Middle East, international terrorism and extremism. As a journalist, he worked for local edition of Sueddeutsche Zeitung in Erding, weekly magazine Quick where he was a chief reporter, and for Stern and Spiegel. From 19932004 he worked in magazine Focus. During that time he was recruited to work for BND. He is also author of 15 books which, some of them, becames bestsellers. He was a co-founder and vicepresident of Institut fuer Terrorismusforschung und Sicheheitspolitik in Essen, Germany.

Paper is published in: Vol. 10 No. 3-4, 2009.

Antonia Dimou, is Diplomatic Advisor at the Hellenic Parliament and Fellow at the Center for Strategic Studies, University of Jordan; and, the Center for Middle East Development, University of California, Los Angeles.

Papers are published in: Vol. 17 No. 1-2, 2016; Vol. 18 No. 1-2, 2017.

Duško Doder, is a journalist and author, whose latest book is Milošević: Portrait of a Tyrant (2000). He has reported extensively on Soviet and East European affairs for the Washington Post, where he served as assistant foreign editor, State Department correspondent, East European bureau chief, Moscow bureau chief, and intelligence correspondent. Doder also served a tour of duty as Beijing correspondent for US News and World Report. He graduated from Washington University, St. Louis, in 1962, and received two advanced degrees from Columbia University. He won two Overseas 
Press Club awards and the Edward Weintal Prize for Diplomatic Reporting. Doder's book Shadows and Whispers: Power Politics Inside the Kremlin from Brezhnev to Gorbachev was the runner-up for the Washington Monthly's Political Book of 1986. Other books include: The Yugoslavs (1977) and Gorbachev: Heretic in the Kremlin (1990).

Paper is published in: Vol. 1 No. 3-4, 2000.

Radoslav Dodig, rođen 1954. u Ljubuškom (BiH). Završio Filozofski fakultet, zaposlen u Mostaru. Član Hrvatskog arheološkog društva, Hrvatskog filolofoškog društva i urednik u biblioteci "Stećak" nakladničke kuće ZIRAL u Mostaru. Objavljuje radove u stručnim časopisisma, te kolumne i komentare u dnevnim novinama.

Paper is published in: Vol. 6 No. 3-4, 2005.

Admiral Davor Domazet-Lošo (b. 1948, Sinj, Croatia). Military education: Navy Military Academy, (1971), Command - Staff Tactics and Operations School (1984), War Strategy School (1991). Ranks: Rear Admiral, (1994), Vice Admiral, (1998), Admiral, (2000). Assignments: Assistant or Commander on several types of ships, Commander of the "Split" Missile Frigate, anti-submarine and anti-missile defence specialist on war ships (1987), Head of Intelligence Analytics Department in the Military Maritime Zone (1991), Chief of the Strategic Research Office (1991), Chief of the Intelligence Department of the General Staff of the Armed Forces (GS AF of the Republic of Croatia, 1992), Deputy Chief of GS AF of Croatia (1996), Chief of the General Staff of the Armed Forces of the Republic of Croatia (19982000). Admiral Domazet deals primarily with 
strategic studies, and writes and publishes essays in the fields of general strategy, military strategy, doctrine and tactics. He also lectures at upper level civilian and military educational institutions.

Papers are published in: Vol. 1 No. 1, 2000; Vol. 11 No. 1, 2010.

Srećko Domljanović (b. 1968, Rijeka, Croatia). Holds B.Sc. in Naval Architecture from the University of Zagreb, Croatia. In September 1995, joined Military-Technical Council of the Ministry of Defense of Croatia and performed various duties dealing with technical and organizationmodernization projects of the Croatian Armed Forces. Earned MS in 1998 at the Industrial College of Armed Forces, National Defense University, in the United States. Has worked in the Institute of Defense Studies, Research and Development since July 1999. Married since 1999.

Paper is published in: Vol. 1 No. 1, 2000.

Dr. sc. Roman Domović, is a lecturer at the Zagreb University of Applied Sciences at the Department of Information Technology and Computing. He went to $X$. mathematical gymnasium where he graduated physics, after which he attended University of Zagreb and graduated in the field of Information sciences and Phonetics. At the same university he earned his doctoral degree in the field of Information and Communication sciences. His research interests are applied cryptography, classical cryptography and information warfare. $\mathrm{He}$ is an author of several scientific and 
professional articles in the field of Information and Communication sciences.

Papers are published in: Vol. 11 No. 2-3, 2010; Vol. 14 No. 1, 2013; Vol. 14 No. 2, 2013; Vol. 14 No. 3-4, 2013; Vol. 16 No. 2-3, 2015.

Mr. sc. Tomislav Đozić, rođen je u Zagrebu 1967. gdje je završio osnovnu i srednju školu. Magistrirao je 2002. godine na poslijediplomskom studiju Međunarodni odnosi na Fakultetu političkih znanosti u Zagrebu s temom "Gospodarska špijunaža u posthladnoratovskom svijetu“. Na istom fakultetu je diplomirao 1991. (smjer politologija). Zaposlen je u Uredu Vijeća za nacionalnu sigurnost od njegovog osnivanja 2003., na radnom mjestu višeg stručnog savjetnika. Prije toga je radio na analitičkim i operativnim poslovima u okviru MUP-a od 1992. Bio je sudionik različitih konferencija i predavač na stručnim seminarima s temama kao što su: poslovna sigurnost, business intelligence, gospodarska špijunaža i slično. Objavio je nekoliko stručnih radova iz tog područja.

Paper is published in: Vol. 13 No. 3, 2012.

Josip Esterajher - Paper is published in: Vol. 1 No. 1, 2000.

Mr. Drago Ferš (b. 1943 Maribor, Slovenia). Education: Faculty of Political Science, University of Ljubljana. Retired in 2000 as Director of Slovenian Intelligence and Security Service (SOVA, Slovenia).

Paper is published in: Vol. 3 No. 1-2, 2002.

Prof. dr. sc. Laris Gaiser, is Assistant Professor at Università Cattolica del Sacro Cuore - Milano. 
Papers are published in: Vol. 18 No. 1-2, 2017; Vol. 19 No. 1-2, 2018.

Heinz Gärtner - Paper is published in: Vol. 2 No. 1-2, 2001.

Heinz Grozev - Paper is published in: Vol. 1 No. 2, 2000.

Professor Heinz Gärtner, Since 1979, Senior Researcher at the Austrian Institute for International Affairs, Vienna. 1997-2000 Guest Professor at the Institute for Political Science at the University of Vienna. Lecturer at the Universities of Vienna, Salzburg and Innsbruck. Resident Fellow at the Institute for East-West Security Studies in New York (Sept. 1987 - June 1989); Visiting Fellow at St. Hugh's College, Oxford (April - July 1992); Visiting Fellow at the Institute for International Relations, Vancouver, Canada (July - August 1993); Guest Professor at the University of Erlangen (Winter 1994/95); Visiting Austrian Professor (Austrian Chair) at Stanford University, 2001/2001. Member of the editorial board of various international and Austrian Journals. Has published widely on European and International Security, the Concept of Security, State and Ethnic Conflicts, Small States, and International Relations Theory.

Paper is published in: Vol. 2 No. 1-2, 2001.

Robert Gates (b. 1943, Kansas). He graduated with honors from the College of William and Mary in 1964, received a Masters degree from Indiana University in 1966, and a Ph.D. from Georgetown University 1974. He joined the Central Intelligence Agency (CIA) in 1966 as an analyst. from 1971 to 1973 , he served as a staff member and intellgience advisor to the US 
Strategic Arms Limitations Talks Delegation. From 1974 - 1976, he was detailed to the National Security Council (NSC) staff. In 1977, he was reassigned to the NSC staff where he was Special Assistant to the National Security Advisor, Dr. Zbigniew Brzezinski. In 1979, he returned to the CIA. Shortly thereafter, he was promoted to the position of Executive Assistant to the Director of Central Intelligence (DCI), and was given additional senior level assignments. In 1982, he was named Deputy Director for Intelligence, where he was responsible for CIA analysis and production. He held this position until April, 1986, when he was nominated and confirmed as Deputy Director of Central Itnelligence. In January, 1989 he was named Deputy Assistant to the President for National Security Affairs. He was the Director of Central Intelligence from November 1991 - January 1993. He started his career as an intelligence officer in $\mathrm{CIA}$ and enroute to the position of $\mathrm{DCl}$ worked in the White House staffs of four presidents.

Paper is published in: Nacionalna sigurnost i budućnost (zbornik, svezak 1, 2001)

Dr. sc. Janos Gömbös (b. 1949, Magyargences, Hungary). Graduted from the Military Academy Lalka Mate in 1968 as a radar technician. Military College "Zrinji Miklos" in 1978. Retired as Colonel in 1993. Doctorate awarded in 1989. Senior fellow for the Center for Security and Defence Studies from 1991. Military Advisor for the Parliamentary Faction of the Hungarian Socialist Party from 1994. Book: Hungary and NATO. Many studies, including: NATO new strategy (1991); Russian foreign policy (1999); Hungarian Defence Industry (1998). Married and has one daughter. 
Paper is published in: vol. 2, no. 3-4, 2001.

Boris Guberina, Ured za upravljanje u hitnim situacijama, Zagreb, Hrvatska.

Papers are published in: Vol. 17 No. 1-2, 2016; Vol. 18 No. 1-2, 2017; Vol. 19 No. 1-2, 2018.

Marijan Gubić, formally served as Assistant Presidential Advisor for International Public Affairs in the Office of the President, Zagreb, Croatia, and as a Counsellor for Public Diplomacy at the Croatian Embassy in Washington, D.C. He holds degrees in Law and Political Science (Honours) and also received a Master's Degree in International Affairs. He currently works as a Consultant for Marketing and Business Information Services.

Papers are published in: Vol. 1 No. 1, 2000; Vol. 1 No. 3-4, 2000; Vol. 2 No. 3-4, 2001.

Dr. sc. Adrian Hänni, is a historian and a lecturer at Distance Learning University Switzerland, where he is responsible for the Political History module. In 2018, he also works as a Visiting Researcher at the Centre for the History of Violence at the University of Newcastle, Australia, and as a lecturer at the University of Zurich. Previously he has been a post-doctoral fellow at Leiden University and a Visiting Fellow at the German Historical Institute in Washington DC. His research interests include the history of intelligence services, propaganda, and terrorism with a focus on the Cold War era. His latest monograph, Terrorismus als Konstrukt ("Terrorism as a Construct"), was published in January 2018. 
Paper is published in: Vol. 19 No. 1-2, 2018.

Predrag Haramija - curriculum vitae is not available.

Papers are published in: Vol. 1 No. 1, 2000; Vol. 1 No. 3-4, 2000.

Dr. sc. Branko Hebrang, dekan je Visoke škole za odnose s javnošću i studij medija Kairos iz Zagreba gdje predaje Osnove teorije promidžbe, a na Hrvatskim studijima Sveučilišta u Zagrebu kolegij Teorije i sustavi agencijskog komuniciranja. Uže područje njegova znanstvenog proučavanja obuhvaća teoriju masovnih medija, upravljanje javnim znanjem, diskurs uvjeravanja i promidžbe u medijskoj praksi, dominaciju političkoga determinizma u medijskoj sferi. Autor je i urednik više projekata, stručnih, znanstvenih i publicističkih radova. Završio je ekonomski fakultet, magistrirao je na Fakultetu političkih znanosti u Zagrebu i doktorirao informacijske i komunikacijske znanosti na zagrebačkom Filozofskom fakultetu.

Paper is published in: Vol. 13 No. 1-2, 2012.

Dr. sc. Neven Henigsberg (b. 1963). Psychiatrist. Since 1991 has worked on health-related humanitarian activities, particularly on development of disaster management information system. From 1993 assumed position of Assistant Director of the Center for Development of Disaster Management Information System at the Medical School in Zagreb. Has led several humanitarian projects in cooperation with WHO, UNHCR and EC. Currently employed at the Medical School in Zagreb, Croatian Institute for Brain Research and Vrapee Psychiatric Hospital. 
Paper is published in: Vol. 1 No. 2, 2000.

Sean Hilscher, graduate of Providence College, served as an intern at the Institute of World Politics in the summer of 2007 . He is now a student at Blackfriars Hall, Oxford University.

Paper is published in: Vol. 9 No. 3, 2008.

Prof. dr. sc. Željko Holjevac, zaposlen je na Odsjeku za povijest Filozofskoga fakulteta Sveučilišta u Zagrebu. $U$ fokusu njegova znanstvenonastavnog rada je hrvatska povijest ranoga novoga vijeka i 19. stoljeća u europskom kontekstu, posebice povijest hrvatskomađarskih odnosa. Istraživački je više puta boravio u inozemstvu, radeći najviše u arhivima i knjižnicama u Beču i Budimpešti. Predsjednik je Društva za hrvatsku povjesnicu i član Organizacijskog odbora Međunarodnog kulturno-povijesnog simpozija Mogersdorf. Kao autor ili suautor objavio je nekoliko knjiga i niz znanstvenih radova, uredio nekoliko zbornika radova i uredničkih knjiga, a okušao se i u pisanju udžbenika povijesti za osnovne i srednje škole.

Paper is published in: Vol. 19 No. 3, 2018.

Gordana Iličić, M.A., born in 1971 in Imotski, Croatia. She graduated Politology at the Faculty of Political science in Zagreb (elections and political parties), where she also earned her Master's degree in Europian Studies - Croatia and Europe (international relationships and national security). She lives and works in Grude, $\mathrm{BiH}$.

Paper is published in: Vol. 9 No. 3, 2008. 
Ambassador Victor Jackovich (b. 1948, Des Moines, lowa, USA). He graduated from Indiana University and attained an M.A. there in 1971. He has specialized in East European, Russian, and Balkan affairs, and maintains fluency in several languages of these regions. In August 1999, Victor Jackovich assumed a newly created State Department position of Associate Director at the George C. Marshall European Center for Security Studies in Garmisch, Germany. Ambassador Jackovich's most recent postings abroad were as U.S. Ambassador to Slovenia (1995-1998), U.S. Ambassador to Bosnia and Herzegovina (1992-1995) and Chief of the U.S. Mission to Moldova (1992). He opened the American Embassy in Bosnia (1994) and served there during the war. Other assignments have included U.S. Cultural Attaché in Moscow, Russia (1988-1990); U.S. Press Attaché in Nairobi, Kenya (1983-1986); and U.S. Cultural Attaché in Bucharest, Romania (1980-1983). Among his many awards for exceptional service are: the Distinguished Presidential Award (1994) for service in the Balkans; and the American Bar Association's Max Kampelman Award (1998) . In addition, he holds the Golden Eagle Award (1995), which is the national medal of the Republic of Bosnia and Herzegovina, and the Serb Civic Society Award (1999). In 2000, he was awarded an honorary degree from the University of Sarajevo and declared an "honorary citizen of Sarajevo." Ambassador Jackovich is married to the former Deborah Jones and has one son, Jacob.

Paper is published in: Vol. 1 No. 3-4, 2000.

Lt Gen. Carlo Jean, was born in Mondovi (Cuneo) on 1 2th October 1 936. He attended the Military Academy in Modena from 1953 to 1955, the 
Service Branch School in Torino from 1955 to 1957, the Italian and French Senior Staff College, and the Center for High Defense Studies. During his Army Staff tenure, he served as Chief of the Office of Financial and Budget Planning of Army Staff and Chief of the IVth Logistics Department of Defense Staff. He commanded the Tactical Group "Susa", the Italian Unit of the NATO Mobile Force, and the Alpine Brigade "Cadore". From 1979 to 1982, he was in charge of public investment verifications and investment funds on employment planning on behalf of the Economic Planning Ministry. In 1980, he was appointed Secretary of the Government, Special Ministerial Committee, which was created to assess the damage caused by the "Irpinia" earthquake. 1981 - 85: consultant at the Institute of International Sociology of Gorizia - Department of Mass Emergencies. 1982 - 85: consultant of the Minister for Civil Protection Commission for Macro - Hazards, and institutional communications during emergencies. 1987 - 89: Director of the Military Center of Strategic Studies. 1988 - 91; 1993 94: member of consultant group at the Ministry of Foreign Affairs for Italian Foreign Policy planning. From September 1990 to May 1992, he served as Military Adviser to the President of the Italian Republic. From January 1994 to September 1997, he was President of the Center for High Defense Studies. After graduating in Political Science, was former professor of Strategic Studies of State University of Gorizia, and at present is professor of Strategic Studies at the LUISS University in Rome. He is author of more than 200 articles on strategy, tactics, logistics, 
international politics, and geo-economics. He has lectured on international politics, geoeconomics, strategy and military policy in several universities and centers of Strategic Studies in Europe, United States, Middle East, North Africa, and Central Asia. He is member of the Scientific Board of "Limes", Italian Review of Geopolitics. From October 1997 to March 2001, he was The Personal Representative of the OSCE Chairman in Office for art. II (CSBM) and IV (Subregional Arms Control) Annex 1 -B of the Dayton Peace Accords for Bosnia and Hercegovina.

Paper is published in: Vol. 2 No. 1-2, 2001.

Dr. sc. Miloš Judaš (b. 1961 in Petrinja, Croatia). Assistant Professor of Neuroscience and Anatomy, School of Medicine, University of Zagreb. Graduated from the School of Medicine, Zagreb, 1984; served with the Medical Headquarters of the Republic of Croatia (19911995) and Center for Crisis Management of the School of Medicine Zagreb (1993 - ). Vice-Dean for Research at the School of Medicine (19982000). Currently engaged in the scientific research program of the Croatian Institute for Brain Research in the field of developmental neurobiology and neuroscience.

Paper is published in: Vol. 1 No. 2, 2000.

Dr. sc. Pavle Kalinić, Office for Emergency Crisis Management, City of Zagreb (Ured za upravljanje u hitnim situacijama, Zagreb, Hrvatska), graduated from the Faculty of Political Science of the University of Zagreb in 1982. In the same year, he received his master's degree in International Relations. He worked as an Assistant Professor at the 
University of Political Science from 1986 to 1987, and at the College of Technical Science from 1987 to 1991. In 1989-1990, as an assistant at the Faculty of Political Science, he participated in the scientific project "Characteristics of Political Behaviour in the Region". In 1989 he founded Fokus, the first independent magazine in Croatia, which was published until the end of 1990. During 1991, he participated in the Homeland War as an army officer. He underwent medical treatment in the US after being wounded on the battlefield. He resided in the United States the following two years, returning to Croatia in 1994. He worked for the Croatian Helsinki Committee for Human Rights in 1994 and 1995. In 1997, he became a member of the Zagreb City Assembly, as well as a member of the Croatian Parliament in 2000. In 2006, he became head of the Department of Education, Culture and Sports in Zagreb; as of 2008, he is the head of the Zagreb Office of Emergency Management. In July 2012, he obtained his $\mathrm{PhD}$ with the thesis "The politics of G.W. Bush administration and Islamic terrorism".

Papers are published in: Vol. 17 No. 1-2, 2016; Vol. 18 No. 1-2, 2017; Vol. 19 No. 1-2, 2018; Vol. 16 No. 2-3, 2015.

Michael G. Karnavas, is an American trained lawyer. He is licensed in Alaska and Massachusetts and is qualified to appear before the various International tribunals, including the International Criminal Court (ICC). Residing and practicing primarily in The Hague, he is recognized as an expert in international criminal defence, including, pre-trial, trial, and appel late advocacy. 
Paper is published in: Vol. 18 No. 3, 2017.

Richard J. Kerr, (b. 1935) retired in 1992 as Deputy Director of Central Intelligence. He headed two of the principal directorates and several offices in the CIA over a 32-year-career. Currently serves on several private sector boards and US government panels.

Paper is published in: Vol. 1, No. 3-4, 2000.

Helena S. Khotkova, (b. 1955) is a political scientist specializing on Central Europe. She graduated from the Moscow University, Faculty of History (1977), Ph.D. (History) the Moscow University, 1983. Since 1998 has been a head of department at Russia's Institute for Strategic Studies. She is the author of numerous sholarly articles. "Russia' $S$ and the CEE countries relations in the context of NATO and the EU enlargment"- In: Stability and Security of Eastern and South-Eastern Europe (Collection studies of Center for Stategic Studies), Ljubljana,1997; Relations between the Russian Federation, the CEE countries and NATO. In: The Geopolitical Position of Central Europe. Development Tendencies in the 21 st Century. Bratislava,1998.

Paper is published in: Vol. 3 No. 1-2, 2002.

Stribor Kikerec - Paper is published in: Vol. 1 No. 1, 2000.

Brigadir dr. sc. Vilko Klasan, rođen 1963. u Ivanjskoj, Bosna i Hercegovina. Osnovnu školu završio je u Ivanjskoj. $\mathrm{Na}$ Zrakoplovno tehničkoj vojnoj akademiji u Rajlovcu kod Sarajeva diplomirao je 1985. Vojno-diplomatsku školu u Zagrebu završio je 1998. Ratnu školu OS SR Njemačke na kojoj je apsolvirao područja iz domene 
sigurnosne politike, proliferacije oružja za masovno uništavanje, kriznog managementa, sigurnosti EU, informacijskog ratovanja i vođenja zračnog rata pohađao je 2000-2001. General Military English Course na National Defence University Budapest, Republika Mađarska završio je 2002. Usavršavao se na području borbe protiv NKB terorizma. Magistrirao je na Visokoj školi sigurnosti sa temom Utjecaj proliferacije OMU na sigurnost EU, a od 2009. je na Poslijediplomskom doktorskom studiju Odsjeka informacijskih zananosti Filozofskog fakulteta u Zagrebu. U obranu Republike Hrvatske uključio se 1991. i obnašao dužnosti od zapovjednika vojarne, bojne, baze do dužnosti u Glavnom stožeru $\mathrm{OSRH}, \mathrm{MORH}$ i Vojno sigurnosnoj agenciji. Za doprinos u ratu odlikovan je Spomenicom domovinskog rata, Spomenicom domovinske zahvalnosti i medaljom Oluja. Dužnost Vojnog izaslanika obrane $\mathrm{RH}$ pri veleposlanstvima $\mathrm{RH}$ u SR Njemačkoj i Češkoj Republici, sa sjedištem u Berlinu obnašao je od 2004-2009. Nakon povratka imenovan je načelnikom Službe za ugovaranje i nabavu MORH, a zatim i načelnikom Samostalnog sektora za javnu nabavu MORH. Od 1. prosinca 2012. je na dužnosti Vojnog izaslanika obrane $\mathrm{RH}$ pri veleposlanstvima $\mathrm{RH}$ u Republici Austriji, Slovačkoj Republici i Švicarskoj Konfederaciji, sa sjedištem u Beču.

Papers are published in: Vol. 10 No. 2, 2009; Vol. 13 No. 1-2, 2012.

Mr. sc. Tomica Kosić. Education: holds Mr. sc. in the field of Information Science from the Faculty of Organisation and Informatics, Varaždin, Croatia. He is a Professor and Higher Scientific 
Assistant at the University of Zagreb, Faculty of Architecture; studied design in Zagreb (Croatia). His research interests include: design and information science models (operative and strategic), relations between information design and informational and modern business development, and approaches to classical and modern information design systems, especially in the field of modelling and design analysis. $\mathrm{He}$ has published more than 10 papers on scientific aspects of modelling in informatics and information design. $\mathrm{He}$ is finishing his doctoral thesis on aspects and relations between information design and modern business for Croatian design companies.

Paper is published in: Vol. 3 No. 1-2, 2002.

Dr. Ivica Kostović, (b. 1943 in Zagreb, Croatia) Professor of Neuroscience and Anatomy, School of Medicine, University of Zagreb. Graduated from the School of Medicine, Zagreb, 1967. Visiting Assistant Professor at Harvard Medical School in Boston (1975-1976), Consultant for human neuroanatomy at the Yale University School of Medicine (1979 - ), Spinoza Professor at the University of Amsterdam (1990 - ). Former Deputy Head of the Medical Headquarters of the Republic of Croatia (1991-1995). Currently Director of the Croatian Institute for Brain Research at the School of Medicine, Zagreb.

Paper is published in: Vol. 1 No. 2, 2000.

Mr. sc. Siniša Košutić, magistrirao je na temu Sustava ranog upozoravanja. Bio je višegodišnji član Strategic and Competitive Intelligence Professionals (SCIP), najveće svjetske organizacije koja okuplja profesionalce iz područja Business Intelligence-a. Zaposlen je u Hrvatskoj 
gospodarskoj komori gdje izrađuje političke analize pojedinih zemalja.

Paper is published in: Vol. 13 No. 3, 2012.

Damir Kovač, project manager at Adriatic Security Solutions d.o.o., born in 1970 in Baden, Switzerland, earned his bachelor's degree from the Polytechnic Electrical Engineering Faculty and later graduated from the University of Zagreb, Faculty of Transport and Traffic Sciences. Previously actively involved in research and development of mobile core networks on projects like GPRS Gateway Support Node, Policy Control Server, Intelligent Packet Solution, Packet Data Gateway. Currently involved in security systems design, project management and consulting.

Papers are published in: Vol. 17 No. 1-2, 2016; Vol. 18 No. 1-2, 2017.

Slavko Krajcar, University of Zagreb, Faculty of Electrical Engineering and Computing, Zagreb, Croatia.

Paper is published in: Vol. 17 No. 1-2, 2016.

Admiral Pierre Lacoste, (born 1924, Paris) Admiral in the 2nd General Officers Section of the Navy. Education: Lycee Saint Louis, Paris. Diploma: Engineer, Naval School. Career: Fled France in 1943 to join the French Freedom Forces in Morocco. 42-year career as an Officer in the National Navy, which began in 1943 with World War II in Indochina and Algeria. Held posts on various ships and in the Headquarters, Officer of Transmissions, Sea Commander, Center for High Military Studies. 1976 - Commander of the Superior War Naval School. 1978 - Military 
Cabinet Chief for the 1st Minister, Raymond Barre. 1980 - Commander of the Mediterranean Fleet. 1982 - General Director of the DGSE (Securite Exterieure) until reaching the age limit in 1985. 1986 - President of the National Defence Studies Foundation. 1989 - President of the Committee for National Liaison "National Army Defence" (DAN) of the Civic Information Center. 1993 - President of the Defence Scientific Studies Center (CESD) at the University of Marne la Vallee. Published Works: "Naval Strategies of Today" 1986; "The Mafia against Democracy" 1992; "An Admiral Bound to Secrecy", 1997; "Intelligence, The French Way", 1998. His most recent publication is a report based on a three year-seminar at the University of Marne la Vallee, entitled "Le renseignement a la française". Decorations: Grand Officer of the Legion of Honor, Maritime Merit Officer, Evasion Medal, Member of the Naval Academy.

Paper is published in: Vol. 1, No. 3-4, 2000.

Prof. dr. sc. Klaus Lange, Director od Institute for Transnational Studies, Landshut; Head of Dept. for International Security Politics, Hanns Seidel Foundation, Munich; Honorary member of MCC, London, and member of RUSI, London. Member, International advisory board, Centre for Global and Strategic Studies, Russian Academy of Sciences. Co-editor, journal "Sicherheitspolitik", Zurich. Teaching: Hochschule für Politik, Munich; UNISA, Pretoria; International University, Moscow; Regional Areas Studies Centre, University of Peshawar.

Paper is published in: Vol. 1, No. 3-4, 2000. 
Brigadier General (Res.) dr. sc. Ephraim Lapid, has a rich career in military and public service in Israel. He served as a Senior Intelligence officer and Spokesperson of the Israel Defense Forces (I.D.F). He was an instructor in the Israeli National Defense College. After retiring from the Israeli military, he served as a senior official in the Jewish Agency. He is a lecturer at the Bar-llan and Haifa Universities. Ephraim Lapid holds an M.A. in Political Science from the University of Haifa, and a teaching certificate. $\mathrm{He}$ received his Ph.D. at the Bar-Ilan University.

Paper is published in: Vol. 17 No. 1-2, 2016.

Dr. med. Lidija Lasić (Bilić Pešić), rođena je u Zagrebu gdje je diplomirala na Medicinskom fakultetu. Završila je poslijediplomski studij iz opće medicine, specijalizaciju iz opće medicine te UZV abdominalnih organa. Početkom 1991. angažira se u Civilnoj zaštiti u DZ Medvešćak. Dragovoljac je Domovinskog rata od 1.8.1991. kad počinje raditi kao rukovoditelj skladišta lijekova i opreme u Glavnom sanitetskom stožeru. Od 1.7.1992. istu dužnost obavlja u MO RH u Upravi za zdravstvo. Jedan je od osnivača humanitarne udruge „Donum“ koja je dovela do osnivanja SOS-dječjeg sela u Hrvatskoj. Sudjelovala je 1992. u osnivanju Svjetskog zbora hrvatskih liječnika (WACP). Godine 1995. otvara privatnu ordinaciju opće medicine u Zagrebu.

Paper is published in: Vol. 13 No. 4, 2012.

Jan Leijonhielm, Head of Bureau, Defense Research Agency, Stockholm, Sweden.

Paper is published in: Vol. 1 No. 3-4, 2000. 
Lt. General Nicolai Leonov, (b. 1928, Riazan) Graduated from Moscow Institute of International Relations. From 1952 to 1958 worked in Ministry of Foreign Affairs of the USSR. In 1958 joined the First Main Directorate of the KGB (external intelligence service). In 1962 - 1968 served in Mexico. In 1969 was appointed the Sub - Director of the Latin American Department of the Intelligence service. In 1971, moved to the Department of Information and Analyses of the First Main Directorate. Two years later was appointed Director of this Department. In 1984, became the Deputy Director of the First Main Department. In 1991 (from February to August) was the Director of the Department of Analyses of the KGB. Since August, 1991, employed as professor and journalist.

Paper is published in: Vol. 1 No. 3-4, 2000.

Maj. Gen. Alexander Anatolevich Liakhovsky, (b. 1946, Tbilisi) Military education - Supreme Army Command Educational Institute, Bakin, Azerbaijan; Military Academy "M. V. Frunze" and Soviet Army General HQ Military Academy. Assignments: As commander of a motorized tank unit, took part in the 1968 events in Czechoslovakia. Spent a long period of time working in the General HQ. Served in various conflict zones in several countries, such as Ethiopia (1983), Angola (1984) and Afghanistan (1987 - 89). Within the Territorial Army Chief Command, was entrusted on numerous occasions with missions to hot -spots in the Soviet Union and in Russia (Armenia, Georgia, South Ossetia, the Baltic region, Tajikistan, and the Northern Caucasus) where he was tasked to normalize the situation in those respective areas. Currently serves as deputy chief of one 
of the directorates of the Chief Directorate of the Territorial Army. His current army rank is General Major. Author of a number of articles on local wars, which have been published in journals and newspapers. Also author of three books: The Secrets of the Afghan War, The Tragedy and Glory of Afghanistan, and The Flames of Afghanistan. Received the USSR Ministry of Defense Award for his article "On the Scorched Afghan Land" in 1990.

Paper is published in: Vol. 1 No. 1, 2000.

Dr. sc. Andrew Liaropoulos, is currently a Senior Analyst at the Research Institute for European and American Studies (RIEAS) in Athens and teaches the postgraduate course 'Foreign Policy Analysis' at the University of Indianapolis, Athens Campus. During the period 2000-2001 he worked as a Research Analyst for the Scientific Committee of the Ministry of Defence and the Naval War College in Athens. He earned his Master's Degree in Intelligence \& Strategic Studies at Aberystwyth University in 2002 and his Doctorate Diploma at Swansea University in 2006. His research interests include international relations, security, intelligence, strategy, military transformation, crisis management and Greek security policy. Dr. Liaropoulos has presented papers in international conferences and published a number of articles in both Greek and foreign journals.

Paper is published in: Vol. 9 No. 3, 2008.

Marko Lončar, rođ. 1971. u Zagrebu, završio studij povijesti u Hrvatskoj i inozemstvu. Predaje povijest u 
osnovnoj školi. Istražuje teme povezane s Domovinskim ratom koje izazivaju kontroverze.

Paper is published in: Vol. 11 No. 2-3, 2010.

Ante Lucic, (b. 1988, Zagreb, Croatia) is a graduate of Jacobs University Bremen, Germany, where he obtained a BA in International Politics and History. Having spent several years in the Middle East, he has become acquainted with the region's political, historical, and security affairs. Besides formal studies, he has chaired a number of civil initiatives in Syria and Germany, and completed two consulting internships in Croatia. He is one of the founders of the Jacobs University's student radio "Pledari Grond," he organized and participated in many student conferences, and is a member of Matica Hrvatska. Ante Lucic is a prospective Master student in the field of Intelligence, Security and Counterterrorism. His areas of research are mostly the Middle Eastern and Balkan politics and security.

Paper is published in: Vol. 10 No. 1, 2009.

Ivica Lučić, (born 1962. Ljubuški, Bosnia-Herzegovina) Law Faculty Assistant at University of Mostar, (Bosnia and Herzegovina); lecturer at the Intelligence Academy in Zagreb (Republic of Croatia). Performed various official duties since 1991 in the area of security and intelligence in Bosnia and Herzegovina and the Republic of Croatia. After the war, awarded rank of MajorGeneral. Elected twice to the Parliament of Bosnia and Herzegovina, where he was Deputy President of the Commission of Defense and Security of the House of Representatives of the Parliament of the Bosnia and Herzegovina Federation. 
Papers are published in: Vol. 1 No. 2, 2000; Vol. 1 No. 3-4, 2000; Vol. 2 No. 3-4, 2001; Vol. 6 No. 3-4, 2005; Vol. 9 No. 3, 2008; Vol. 10 No. 1,2009

Ivan Krešimir Lukić - Paper is published in: Vol. 1 No. 1, 2000.

Prof. Reneo Lukic, was born December 14, 1951 Požega, Croatia. Since 1995, has been a permanent resident in Canada. In 1989, he was granted a Ph.D. in History and Political Science (specializing in International Relations), Graduate Institute of International Studies, Geneva, Switzerland with his dissertation: "The process of political autonomy of the Yugoslav Communist Party with respect to the Comintern and the Soviet Union, 1941 -1 944." Since May 1995, he has been employed as Associate Professor of International Relations, Department of History, Laval University (Quebec, Canada). He is also Senior fellow at the Institut Québécois des Hautes Etudes Internationales. Lukic is the author or co-author of numerous books, including: Les relations sovieto yougoslaves de 1935 a 1945 . De la dependence a l'autonomie et a l'alignement. Publications Universitaires Europeennes, Peter Lang, Bern, Switzerland, 1996, 287 p.; Europe from the Balkans to the Urals, Oxford University Press for SIPRI, 1 996, 436 p.; Rethinking the International Conflict in Communist and PostCommunist States. Essays in Honor of Miclos Molnar, Edited by Reneo Lukic. McGillQueen's University Press, Montreal, 1997. (to be released soon); and articles: "La paix américaine pour les Balkans", Etudes Internationales, Quebec, Canada, vol. XXVII, no 3, September 1 996, pp. 553-569; "The 
Russian Federation Will Remain United", Transition, Prague, Vol. 2, no 1, 12th January, 1996, pp. 14-17; "Yugoslavia: Disintegration Through War", Nationalities Paper, New York, vol. 22, no. 1, Spring 1994, pp. 49-70; "Russland und der Krieg im ehemaligen Jugoslawien", Europa Archiv, Bonn, no. 3, February 10, 1994, pp. 80-88; Russian Foreign Policy and the Wars in the Former Yugoslavia", RFE/RL Research Report, Munich, vol. 2, no. 41, October 15, 1993, pp. 25-32.

Paper is published in: Vol. 2 No. 1-2, 2001.

Davor Marijan (b. 1966, Livno, Bosnia-Herzegovina). Holds degrees in history and archaeology from the University of Zagreb, Croatia. Has published works in the area of military history. Author of the monography Battle of Kupres, 1942. (Zagreb: AGM, 1999). Employed in the Military Museum of the Croatian Army in Zagreb.

Papers are published in: Vol. 1 No. 1, 2000; Vol. 2 No. 3-4, 2001.

Dr. sc. Miroslav Međimorec (b. 1942 in Zagreb, Croatia). Education: Faculty of Philosophy, Comparative Literature; Academy for Theatre and Film. 1991. Volunteered in the Croatian Army. 1992 Office of President - Advisor. 1993 - Assistant Minister of Foreign Affairs, Assistant Director of HIS. 1999 - Ambassador to Switzerland. Rođen 4. siječnja 1942. u Zagrebu, na Filozofskom fakultetu diplomirao Komparativnu književnost (1964.) i odslušao poslijediplomski studij književnosti (1965.-1967.). Kazališnu režiju diplomirao 1973. na Akademiji za kazališnu i filmsku umjetnost, iste godine bio na poslijediplomskom kazališnom studiju u Royal Shakespeare Company, London/Stratford on 
Avon. Doktorirao teatrologiju na Filozofskom fakultetu u Zagrebu. Kao profesionalan redatelj u statusu slobodnog umjetnika (1965.-1985.) i stalnog redatelja u Dramskom kazalištu Gavella (od 1985. do 1991.) režirao preko sedamdeset kazališnih predstava, desetak radio-drama, adaptirao i za televiziju snimio nekoliko svojih kazališnih predstava. Prema priči Miodraga Pavića „Crvena kraljica“ režirao televizijski film, televizijsku dramu prema kazališnom komadu Őden von Horvatha „Figarova rastava", film prema pripovijetci „Školjka šumi" Slobodana Novaka te napisao scenario za igranodokumentarni film „Vukovarska pasija“. Za svoju 100-godišnjicu Hrvatsko narodno kazalište iz Osijeka naručilo je i izvelo dramu Miroslava Međimorca "Zastave, barjaci, stjegovi“. Dobitnik je brojnih nagrada za režiju na kazališnim festivalima i smotrama (tri Zlatna lovor-vijenca na MESS-u u Sarajevu, Nagrada grada Zagreba, godišnje nagrade kritike i Udruženja dramskih umjetnika, nagrade na "Gavellinim večerima“, godišnja nagrada "Vladimir Nazor"). Jedan je od osnivača časopisa za kazalište i film „Prolog", o kazalištu je izlagao na "Hvarskim danima", „Sterijinom pozorju" i "Krležinim danima“ i napisao niz teatroloških članaka i rasprava. Napisao romane "Piše Sunja Vukovaru", „Frankfurtska veza" i „Presvijetli i rabin“, povijesnu studiju „Medački džep“ i veći broj raščlambi (povijesnih, izvještajnih, vanjskopolitičkih pitanja). Hrvatski branitelj, dragovoljac, visoki časnik HV-a (stožerni brigadir) i djelatnik Ministarstva obrane $\mathrm{RH}$ (1991.-1993.), pomoćnik ministra vanjskih poslova $\mathrm{RH}$ (1993.-1999.) i pomoćnik ravnatelja HIS-a (1993.-1999.), veleposlanik $\mathrm{RH} u$ Švicarskoj konfederaciji (1999.-2000.) i do 
umirovljenja službenik Ministarstva vanjskih poslova RH. Nositelj visokih državnih odlikovanja za sudjelovanju u Domovinskom ratu i za doprinos razvoju hrvatske diplomacije i izvještajne službe.

Papers are published in: Vol. 1 No. 3-4, 2000; Vol. 2 No. 3-4, 2001; Vol. 3 No. 1-2, 2002; Vol. 3 No. 3-4, 2002; Vol. 4 No. 1-4, 2003; Vol. 5 No. 1-4, 2004; Vol. 9 No. 4, 2008.

Dr. sc. Thomas Patrick Melady, The former U.S. Ambassador to Burundi, Uganda and the Holy See, is President Emeritus of Sacred Heart University. He is now Senior Diplomat.

Papers are published in: Vol. 2 No. 1-2, 2001; Vol. 9 No. 3, 2008.

Dr. sc. Damirka Mihaljević, magistrirala je na Fakultetu političkih znanosti u Zagrebu 2006. godine na temu Utjecaj javnog mnijenja na međunarodne odnose. Na Filozofskom fakultetu u Mostaru 2012. godine obranila doktorski rad na temu Bosna i Hercegovina u potrazi za optimalnim modelom uređenja. Kao asistentica angažirana na kolegijima Političke doktrine i ideologije, Ideološke i političke transformacija jugoistoka Europe na odjelu politologije Filozofskog fakulteta u Mostaru. Objavila je nekoliko radova iz politologije: Utjecaj javnog mnijenja na međunarodne odnose, Odnos morala i politike, Politička kultura.

Papers are published in: Vol. 11 No. 1, 2010; Vol. 14 No. 2, 2013.

Prof. dr. sc. Vine Mihaljević, rođen je 1958. godine u Livnu gdje je završio osnovnu školu. Franjevačku klasičnu gimnaziju završio je u Visokom 1978., 
Franjevačku teologiju u Sarajevu 1980.-1985., diplomirao je na Katoličkom bogoslovnom fakultetu u Zagrebu 1986., poslijediplomski studij iz Pastoralne teologije na Salezijanskom papinskom sveučilištu u Rimu gdje je 1989. godine magistrirao, a 1992. godine doktorirao s temom "CREDO - la catechesi televisiva" („CREDO - televizijska kateheza“). Bio je profesor Pastoralne teologije na Franjevačkoj teologiji - Sarajevo/Samobor 1992.-1993., urednik u „Studiju Kršćanske sadašnjosti“ od 1993.-1997. na audiovizualnim projektima, odnosno video-katehezama za različite uzraste te urednik u teološkom časopisu "Svesci" 1997.-1998. Od 1998. godine do danas radi na Institutu društvenih znanosti Ivo Pilar u Zagrebu kao znanstveni savjetnik na temama "Religijske zajednice u Hrvatskoj i njihova uloga u integracijskim procesima”, «Globalizacija i (post)moderni religijski i crkveni pokreti u Hrvatskoj” te „Hrvatski identitet, religija i izazovi europskih integracija“. Objavio nekoliko knjiga i više znanstvenih i stručnih radova u relevantnim domaćin i stranim znanstvenim publikacijama. Područje znanstvenog zanimanje je sociologija religije, komunikologija, pastoralna teologija.

Paper is published in: Vol. 12 No. 4, 2011.

Veljko Miljević, (1952.) osmogodišnje i gimnazijsko školovanje završio u Kutini i Zagrebu. Diplomirao na Pravnom fakultetu Sveučilišta u Zagrebu 1975. 1978. g. položio je pravosudni ispit te se od 1980. g. u okviru HOK-e bavi slobodnim odvjetništvom. Od 1998. do 2008. član je najužeg rukovodstva Hrvatskog helsinškog odbora, a od 2002. do 2007. član je Odbora za ljudska prava i prava nacionalnih 
manjina Hrvatskog sabora iz reda javnih, znanstvenih i stručnih djelatnika. Od 2006. g. ispitivač je na pravosudnim ispitima Ministarstva pravosuđa RH i to neprekidno do svibnja 2016., te nastavno od 1. lipnja 2018.

Papers are published in: Vol. 19 No. 3, 2018.

Luka Mišetić, represents clients in state, federal and international litigation, including commercial, civil, white-collar criminal and international criminal cases. In business litigation, Mr. Misetic represents corporations and partnerships, as well as their directors, officers and partners in breach of contract and fiduciary duty claims, regulatory matters, trade secrets claims, fraud and negligence suits, and a variety of other claims. Mr. Misetic represented Croatian General Ante Gotovina before the International Criminal Tribunal for the former Yugoslavia in The Hague, The Netherlands.

Paper is published in: Vol. 18 No. 3, 2017.

Mag. pharm. Silvija Missoni, rođena u Zagrebu gdje nakon je završila osnovnu školu, II realnu gimnaziju te farmaceutski fakultet. Nekoliko godina radi $u$ Hannoveru (Njemačka). Povratkom u Zagreb, zapošljava se u ljekarnama „Zagreb“ gdje radi do umirovljenja. Jedna je od osnivača apoteke koja je djelovala u Sveučilišnoj bolnici, Jadranska bb. Dragovoljac je Domovinskog rata od početka veljače 1991. kad se javlja u nenaoružane odrede Narodne zaštite pri zagrebačkoj mjesnoj zajednici Petar Krešimir IV, a potom u naoružane odrede gdje vrši dužnost zapovjednika sanitetskog voda. Paralelno, kao dragovoljac (uz redovni rad u apoteci "Ljekarna Zagreb“) u Caritasu Biskupske konferencije vrši poslove 
organizacije i koordinacije slaganja lijekova iz donacija. Dana 1.5.1991. odlazi u Glavni stožer saniteta $\mathrm{RH}$ gdje razrađuje i ustrojava sustav prihvaćanja, slaganja i distribucije lijekova i sanitetskog materijala. Dana 6.12.1991. postavljena je na dužnost pročelnika Odjela za sanitetsku opskrbu Glavnog stožera saniteta $\mathrm{RH}$. Na toj se dužnosti nalazi do 21.7.1993. kad prelazi na rad u Ministarstvo vanjskih poslova $\mathrm{RH}$. Dana 15.8. odlazi u Generalni konzulat $\mathrm{RH}$ u Zurich, kao tajnik i koordinator za humanitarne poslove i: održavanje kontakta sa Svjetskom zdravstvenom organizacijom; održavanje kontakta s inozemnom farmaceutskom industrijom i koordiniranje $s$ hrvatskom dijasporom za pomoć u obnovi hrvatskih bolnica. Jedan je od osnivača humanitarne udruge „Donum“ koja je dovela do osnivanja SOS-dječjeg sela u Hrvatskoj. Završila je devet razreda glazbene škole, govori tri strana jezika.

Paper is published in: Vol. 13 No. 4, 2012.

Nikola Mlinac - Paper is published in: Vol. 17 No. 3, 2016.

Saša Mrduljaš, Institut društvenih znanosti Ivo Pilar Područni centar Split, Split, Republika Hrvatska.

Paper is published in: Vol. 10 No. 2, 2009.

Yordan Natchev - Paper is published in: Vol. 1 No. 2, 2000.

Dr. sc. Ante Nazor, ravnatelj Hrvatskoga memorijalno dokumentacijskog centra Domovinskoga rata (od utemeljenja 2005. godine). Autor je većeg broja knjiga i znanstvenih radova objavljenih u znanstvenim časopisima i zbornicima. Urednik je niza knjiga i monografija, te sudionik na 
brojnim znanstvenim i stručnim kongresima i skupovima. Predaje na Hrvatskim studijima i Hrvatskom vojnom učilištu kolegije iz suvremene povijesti, vojne povijesti i povijesti Domovinskoga rata.

Paper is published in: Vol. 19 No. 3, 2018.

Dr. sc. John M. Nomikos, is the Director at the Research Institute for European and American Studies. He earned his Bachelor Degree in Sociology at the Northeast Louisiana University in 1987, his Masters Degree in European Integration and Cooperation at the University of Hull, 1991, and his Doctorate Diploma in International Relations and Diplomacy at the Washington International University in 2001. He specializes on transatlantic intelligence studies, intelligence reform, and national security architecture. He has done research and studied in various research institutions in USA, UK, Norway, Finland, Germany and Israel.

Paper is published in: Vol. 9 No. 1-2, 2008; Vol. 17 No. 1-2, 2016; Vol. 19 No. 1-2, 2018.

LTC Steven Oluic, is a career American Army Officer and an Assistant Professor of Geography at the United States Military Academy, New York. He is the author of numerous articles, book chapters and one book. LTC Oluic's research interests include understanding national identity, theories of the state and most recently, the phenomenon of radical Islam in the Balkans. He earned his doctorate at Kent State University in 2005 and instructs courses on the Geography of Russia the Former Soviet Union, the Geography of Europe, and World Regional Geography at the US Military Academy. 
Paper is published in: Vol. 9 No. 1-2, 2008.

Patricia Orglerova, Intern of NATO Energy Security Centre of Excellence.

Paper is published in: Vol. 17 No. 1-2, 2016.

Velimir Ostoić, CEO of Adriatic Security Solutions d.o.o., born in 1950. in Varaždin, Croatia, graduated from the University of Zagreb, Faculty of Transport and Traffic Sciences. He is an entrepreneur mainly involved in project management, consulting, development of threat assessments and risk analysis, security systems design, project revision and facility security plan development. Involved in the area of intelligent transportation systems applications in which he published several papers.

Papers are published in: Vol. 17 No. 1-2, 2016; Vol. 18 No. 1-2, 2017.

Dr. sc. Plamen Ilarionov Pantev (b. 1952). Senior Research Fellow, Ph.D. and Associate Professor in International Relations and International Law at Sofia University "St. Kliment Ohridsky". Expert in security studies, foreign-policy predictions and international negotiations. Founder and Director of the Institute for Security and International Studies (ISIS), Sofia, Bulgaria.

Paper is published in: Vol. 1 No. 1, 2000.

Veerle Pashley, is a PhD student in criminology and social \& military sciences at the Free University of Brussels and the Royal Military Academy.

Paper is published in: Vol. 18 No. 1-2, 2017.

Dražen Penzar - Paper is published in: Vol. 1 No. 1, 2000. 
Nika Pinter, braniteljica generala Slobodana Praljka, svoju je pravničku karijeru započela kao tužiteljica, da bi devedesetih prešla u odvjetnice. Početkom rada Haaškog suda zastupa mnoge optuženike. Zastupala je obranu Dragana Papića, oslobođenog u samom predmetu prije donošenja presuda. Bilo je to $u$ predmetu Kupreškić. U predmetu Kordić - Čerkez zastupala je obranu Marija Čerkeza, u predmetu Naletilić - Martionović sudjelovala u obrani Naletilića, bila je subraniteljica u obrani Paška Ljubičića i na kraju u predmetu Prlić i ostali zastupajući obranu Slobodana Praljka. Provela je 19 godina u sudnici Haaškog suda.

Paper is published in: Vol. 19 No. 3, 2018.

Prof. dr. sc. Iztok Podbregar, is a Full Professor at the Faculty of Organizational Sciences, University of Maribor and Dean. His major interests concern crisis management, critical infrastructure and human resource management. He teaches at undergraduate, master and doctoral level. He is author of several monographs, books, scientific articles published in Slovenia and abroad.

Paper is published in: Vol. 19 No. 1-2, 2018.

Slobodan Praljak, (Čapljina, 2. siječnja 1945. - Haag, 29. studenoga 2017.) završio je tri fakulteta. Godine 1970. diplomirao je kao inženjer elektrotehnike na Elektrotehničkom fakultetu u Zagrebu. Godine 1971. diplomirao je na Filozofskom fakultetu u Zagrebu, filozofiju i sociologiju. Godine 1972. je diplomirao na Akademiji za kazalište, film i televiziju (danas Akademija dramske umjetnosti) u Zagrebu. Predavao je filozofiju i sociologiju. Tijekom sedamdesetih i osamdesetih bio je kazališni redatelj u Zagrebu, 
Osijeku i Mostaru. Bio je general pukovnik Hrvatske vojske i Hrvatskoga vijeća obrane.

Paper is published in: Vol. 18 No. 3, 2017.

Dr. sc. Tonći Prodan, Portus et Navem Split.

Papers are published in: Vol. 16 No. 1, 2015; Vol. 18 No. 1-2, 2017; Vol. 19 No. 1-2, 2018.

Daniel Pustelnik, (b. 1984, Berlin, Germany) is a graduate of Jacobs University Bremen, Germany. His main field of interest is strategy, particularly how factor endowments and their interrelation with player behavior can be systematically analyzed. After graduating from Beethoven Gymnasium in Berlin he moved to Freiburg to study medicine. Upon acquiring the Physikum (Germany's preclinical cumulative exam certificate) in 2007, he moved to Bremen to study International Politics and History at Jacobs University, from where he graduated in 2010 as a BA. His academic foci lay on political economy in general and the role of energy in particular. His interest in strategy extends across the fields of politics, economics, and business. He has been member of several winning teams in debating and business competitions.

Paper is published in: Vol. 10 No. 1, 2009.

Paško Radica, neovisni je politički analitičar.

Paper is published in: Vol. 17 No. 3, 2016.

Dr. sc. Marko Radoš, (b. 1963 in Seonica, B\&H) Medical doctor, resident in radiology and assistant at the School of Medicine, University of Zagreb. Graduated from the School of Medicine, Zagreb, 1990; served with the Medical 
Headquarters of the Republic of Croatia (19911995) and Center for Crisis Management of the School of Medicine, Zagreb (1993 - ). Currently engaged in the scientific research program of the Croatian Institute for Brain Research (neuroradiology and developmental neuroscience).

Paper is published in: Vol. 1 No. 2, 2000.

Lieutenant-General André Ranson, was Director of Military Intelligence (2001-2005).

Paper is published in: Vol. 18 No. 1-2, 2017.

Martin Raguž, Born March 2, 1958 in Stolac, B\&H. Primary and Secondary School completed in Stolac. Faculty of Political Science, Department for Politology, graduated at Zagreb University. Married and father of three children. Positions held: Ministar for Refugees and Social Affairs in the Government of Bosnia and Herzegovina 1992-1993. Head of Office for Refugees and Displaced Persons of Herceg-Bosnia 19931994. Deputy Minister for Refugees and Social Affairs in the Government of the Federation of Bosnia and Herzegovina 1994-1995. Minister without portfolio in the Government of the Federation of Bosnia and Herzegovina 1996; responsible for the coordination of $\mathrm{FBiH}$ Government activities on the implementation of the Peace Agreement for B\&H from Dayton. Head of Office of the Croat Member of the Presidency of B\&H 1997 and 1998. Head of Office of the Croat Member of the Presidency of $\mathrm{B} \& \mathrm{H}$, from 1999 to 2000. Minister for Human Rights and Refugees since June 22, 2000. Chairman of the Council of Ministers of $\mathrm{B} \& \mathrm{H}$ from October 18, 2000. 
Paper is published in: Vol. 2 No. 1-2, 2001.

Michael R. Rousek - Paper is published in: Vol. 17 No. 1-2, 2016.

Željko Sačić - Paper is published in: Vol. 1 No. 3-4, 2000.

Hrvoje Sagrak, is a graduate lawyer with a diploma from the University of Zagreb. He also completed also the Executive MBA two-year postgraduate program at the Cotrugli Business School in Zagreb. He started his professional career in the public sector, working for the Croatian Ministry of Foreign Affairs for 11 years and being posted, among other duties, for two mandates abroad in embassies (Canada and Germany) as Head of Consular Section. Returning to the Ministry, he worked for the Political Analysis Department as a Counsellor. Since 2004 he is in the IT industry, working for leading Croatian IT companies as business development manager and as project director in complex projects. From 2008 to 2012 he held a pro-bono position of the president of the ICT branch association of the Croatian Employers' Association (CEA ICT) and from 2012 to present day, he is Vice-President and Head of the Section for e-Business and e-Government. At INFODOM, Mr. Sagrak has been a sales and marketing director, then director of the Public Sector business line and director of the Export Program. Mr. Sagrak has been leading and supporting several national initiatives through the Croatian Employers Association- ICT branch association, such as Transparency in Procurement of ICT solutions, Standard Project of the Electronic Document Management in Public Sector, and e-Invoicing. He headed an expert team of the CEA ICT in cooperation with 
the Ministry of Administration - Department for e-Croatia for setting up the Strategy of eCroatia 2020.

Paper is published in: Vol. 17 No. 1-2, 2016.

Mr. sc. Andrej Sardelić, rođen 1968. u Zagrebu, diplomirao je 1992. na PTT smjeru Fakulteta prometnih znanosti Sveučilišta u Zagrebu. Magistrirao je 1998. na Ekonomskom fakultetu Sveučilišta u Zagrebu, usmjerenje marketing. Kao stručni ekspert zaposlen je u HP-Hrvatskoj pošti d.d. u Zagrebu. Posebno se bavi istraživanjem poštanske povijesti, primjenjivih poštanskih propisa, tuzemnim i inozemnim trendovima $i$ kretanjima u poštanskoj industriji te fenomenu filatelije i njenog utjecaja na široki spektar ljudskih aktivnosti. Bio je član Povjerenstva za odabir grafičkih i likovnih motiva poštanskih maraka RH (2005.-2009.) Hrvatske pošte d.d.. Sudjelovao je na više hrvatskih i međunarodnih znanstvenih i stručnih skupova iz područja komunikologije, poštanskog prometa, logistike i tržišnih odnosa. Predsjednik je Filatelističkog društva „Poštar“ u Zagrebu.

Paper is published in: Vol. 13 No. 3, 2012.

Lt. General Leonid Vladimirovich Shebarshin (b. 1935, Moscow). Graduated from the Moscow Institute of International Relations, Oriental faculty. In 1958, joined Ministry of Foreign Affairs of the USSR and was posted the same year to the Embassy in Pakistan. In 1962, left the Ministry of Foreign Affairs and joined the First Main Directorate, External Intelligence Service, of the Committee for State Security (KGB) with the rank of lieutenant. From 1964-1977, served in Pakistan and India. In 1979, appointed chief of the KGB 'residentura' in Iran and gained first- 
hand experience of the Islamic revolution. After returning to the Center in 1983, became Deputy Chief of the Analytical Department of Intelligence. In February, 1989, appointed Chief of the First Main Directorate, Deputy Chairman of KGB. In August, 1991, by decree of Mihael Gorbachev, appointed Acting Chairman of $\mathrm{KGB}$, and soon thereafter replaced by $\mathrm{Mr}$. Bakatin. Boris Yeltsin reveals in his memoirs that General Shebarshin was removed from the top position in the KGB at his insistence. In September, 1991, provoked by the incompetence and high - handedness of Mr. Bakatin, General Shebarshin resigns from the KGB with a full pension. At the end of 1991, General Shebarshin, along with a group of former KGB colleagues and Interior Ministry officials, founds a non-governmental company specializing in corporate security, "The Russian National Economic Security Service (RNESS)".

Paper is published in: Vol. 1 No. 1, 2000; Vol. 1 No. 3-4, 2000.

Dipl. iur. Tomo Šimić, rođen 1958. godine u Srednjoj Bosni, sudjelovao je u Domovinskom ratu kao pripadnik HVO. Trgovačko pravo diplomirao je na Mostarskom sveučilištu. Nakon završetka rata, zajedno s obitelji odlazi svojim roditeljima, koji su tada živjeli u srednjoj Njemačkoj. Radio je različite poslove u nekoliko manjih i srednje velikih njemačkih tvrtki. Danas radi u jednoj srednje velikoj banci na poslovima razvoja i upravljanja sustavom.

Papers are published in: Vol. 7 No. 1-2, 2006; Vol. 7 No. 3, 2006; Vol. 7 No. 4, 2006; Vol. 8 No. 1, 2007; Vol. 8 No. 2, 2007; Vol. 8 No. 3, 2007; Vol. 8 No. 4, 2007. 
Dr. sc. Vladimir Šimović, from the Zagreb Faculty of Law, Zagreb, Croatia, 2000, in the field of Information science. Associate Professor at the University of Zagreb; employed full-time at the Police College in Zagreb (Croatia) and part-time at the College for Business and Management in Zapresic (Croatia). Senior researcher and project leader for consulting services and the Official Consultant for the Croatian Custom Directorate (Ministry of Finance of the Republic of Croatia) on relations with the World Bank and Croatian Government Contracts ("Project Trade and Transport Facilitation in Southeast Europe; IBRD Loan No: 4582-HR"). Research interests include: classical and intelligent information systems development problems; aspects (informational and financial, operative and strategic) of various (criminal, competitive or business) intelligence models; modeling aspects in the field of: forensic computing, and digital-payments, and classical and modern statistical systems, especially in field of stochastic simulations, simulation modeling and analysis, and statistical and informational (even artificial intelligence) software tools processes. Has published more than 55 papers and 3 books about information science and modelling aspects (information and financial modelling aspects).

Paper is published in: Vol. 3 No. 1-2, 2002; Vol. 2 No. 3-4, 2001.

Dr. sc. Davor Šinka, was born in Zagreb, Croatia, where he finished his elementary and high school education. He received his B.S. and M.S. degrees in electrical engineering from the Department of Energy and Power Systems at the University of Zagreb, Faculty of Electrical Engineering and Computing. In 2014 he earned 
his Ph.D. from the same department with the thesis titled "Quantitative Terrorism Risk Assessment and Management Method for Energy Systems". Since 1996 he has been employed by a privately owned company ENCONET. His main working areas are technological risk analysis and nuclear/radiological emergency preparedness and response. He participates in various projects in both safety and security domains, where quantitative risk assessment and management methods have to be applied. Also, he organizes education, training and exercises. In the period from 1998 to 2008 he was a member of the centre for providing expert support in case of a nuclear accident, operated by the Croatian State Office for Nuclear Safety. Since 2004, he is a member of the working group for the development of the European early notification and data exchange systems used in the event of a radiological or nuclear emergency. He is an author or co-author of more than 20 scientific or expert articles and more than 40 reports prepared for state institutions and industry. He collaborated on scientific projects sponsored by the Ministry of Science, Education and Sports. $\mathrm{He}$ is a member of the international organization - The Society for Risk Analysis.

Paper is published in: Vol. 17 No. 1-2, 2016.

Dr. sc. Dejan Škanata, was born in 1958. Graduated in 1983 from the University of Zagreb, Faculty of Electrical Engineering and Computing, Croatia. Background in nuclear engineering. In 1996 he carried out the fellowship at Brookhaven National Laboratory, Upton, NY, USA. In 1999 he got a Ph.D. degree with the thesis "A 
Method for Risk Assessment of Radioactive Waste Repository". He has almost 30 years of working experience in the field of Radioactive Waste Management and Risk Analysis. He works as a teaching professor at the University of Zagreb Faculty of Electrical Engineering and Computing (Risk Analysis - postgraduate program) and University of Applied Studies in Velika Gorica (System Reliability and Risk Assessment - graduate program and Corporate Risk and Security - postgraduate program). He participated in several international certified training programs related the Radioactive Waste Management, Nuclear and Radiological Emergency Planning and Risk Assessment and Management. He also participated in several international scientific programs such as: Harmonization of Nuclear Emergency Preparedness (IAEA); Use of Probabilistic Safety Assessment for Nuclear Installations with Large Inventory of Radioactive Materials (IAEA); Integrated Health and Environmental Risk Assessment and Risk Management in Large Industrial Areas (UNEP, WHO, UNIDO, IAEA); and Decommissioning Risk Management (IAEA). He was co-director of the Advanced Research Workshop on Computational Models of Risks to Infrastructure held in Primošten, Croatia, 2006, supported by the NATO Science for Peace and Security Program. He published some 95 professional papers and four books. He won the Josip Juraj Strossmayer Award for scientific contribution in the field of technical sciences for the year 2000 .

Paper is published in: Vol. 17 No. 1-2, 2016.

Douglas Smith, Graduate of Harvard College. Served for five years as an officer in the U.S. Navy prior to joining the CIA. As CIA operations officer, spent 
15 years of his career in Southeastern Europe. He retired in 1997.

Paper is published in: Vol. 1, No. 3-4, 2000.

Dr. Arnon Soffer, (b. 1935, Tel Aviv) Professor of Geography, University of Haifa, Israel. Head of the Chaikin Chair of Geostrategy, University of Haifa. Visiting Prof.: Hebrew University of Jerusalem, University of Utah, Portland State University. National Defense College, Army Command and Staff College, Police Command Staff College. Invited Visits: West Point, University of London. Publications $3: 25$ books and Monographs, 14 educational books, about 200 articles on: Jewish-Arab relations, Military Geography, Demography, Education, Water in the Middle East, Israel, Galilee, Mountain Geography. Articles and interviews in various newspapers and journals including in the New York Times, Los Angeles Times, Chicago Tribune, Scientist Christian Monitor, The Independent, Times, New Scientist, Newsweek, Wall Street Journal, U.S. News and World Report, T.V. and radio appearances in Israel and abroad 1972-2007 (including BBC, The Netherland, Japan, Azerbaijan, Latin America, Canada, U.S.A. (CNN, NBC and local), Denmark, Germany, West Bank and the Arab World).

Paper is published in: Vol. 9 No. 1-2, 2008.

Valentin Krastev Stankov (b. May 22, 1955). He was awarded a Doctor of Philosophy Degree in 1988 and a Doctorate of Science in 2000; in 2001 he became Professor of Heuristics, Balkan ethno-psychology, and National Security. Dr. Stankov speaks English, Spanish, 
French, and Russian. His professional experience includes: 1978-1988 - Ministry of Interior - operational officer; 1988-1991 Academy of Ministry of Interior - professor; 1991-1994 - Executive Director of state-owned company "Knigorazprostranenie"; 1994-2000 in private business; founder and President of "Davco group" Holding; 2002 - Professor at the Academy of the Ministry of Interior. He has written for over 90 publications - including 8 books - several of which were published or printed abroad. Public projects include: Chairman of the Board of the "Potential" foundation, which supports the creative activities of talented, but deprived children: sponsorship of talented children in international music competitions; and supporter of the construction of the Monument in the Academy of Ministry of Interior. In 2002, Dr. Stankov received an invitation from the government of the Republic of Philippines to become its Honorable Consul in Bulgaria.

Paper is published in: Vol. 3 No. 1-2, 2002.

Arian Starov - Paper is published in: Vol. 2 No. 1-2, 2001.

Richard F. Stolz (b. 1925, Dayton, Ohio, USA). He served in the United States Army from 1944 to 1946 as an infantryman with the 100th Infantry Division in Europe. Richard F. Stolz joined the Central Intelligence Agency in 1950. He served overseas for more than 15 years in Eastern and Western Europe. He retired in 1981, but was called back into service in 1988 by then DCl William $\mathrm{H}$. Webster to become the Deputy Director for Operations. He served in that capacity for three years, retiring again at the end of 1990. 
Richard F. Stolz was editor in National Security and The Future (Vol. 9 no. 3, 2008).

Marin Stošić, rear admiral (lower half-ret), Our inconclusiveness to respond on incidents at sea is alarming (in Croatian - Naša neuvjerljivost $u$ rješavanju incidentnih situacija na moru zabrinjava), (2016).

Paper is published in: Vol. 19 No. 1-2, 2018.

Mr. sc. Stjepan Sučić, rođen 1959. u Vukovaru, dragovoljac je Domovinskog rata u kojem je dva puta bio ranjen. Aktivni je sudionik obrane Vukovara od prvog dana organiziranja obrane. Nakon okupacije Vukovara, nastavlja $s$ aktivnim djelovanjem u HV. Obnaša niz odgovornih zapovjednih dužnosti, uključujući i zapovijedanje 5. gbr. HV. Odlikovan je spomenicama Domovinskog rata i Domovinske zahvalnosti, Redom hrvatskog trolista, Redom hrvatskog pletera, Redom hrvatskog križa, Redom Nikole Šubića Zrinskog, Redom Bana Jelačića i Redom Kneza Domagoja s ogrlicom. Umirovljen je u činu brigadira HV. Završio je najviše vojne škole OS RH: Zapovjedno stožernu školu „Blago Zadro“ i Ratnu školu „Ban Josip Jelačić“.

Papers are published in: Vol. 12 No. 3, 2011; Vol. 12 No. 4, 2011.

Prof. dr. sc. Polona Šprajc is an Assistant Professor at the Faculty of Organizational Sciences, University of Maribor in the Department of Personnel and 
Vice dean for educational activity. Her major research interests concern human resource management, marketing and business ethics. She teaches on undergraduate and masterlevel. She is author of chapters in books and articles in scientific and professional journals, published in Slovenia and abroad.

Paper is published in: Vol. 19 No. 1-2, 2018.

Reynaud Theunens, is Chief of the Joint Mission Analysis Centre (JMAC) in the United Nations Interim Force (UNIFIL) in Lebanon since 2009. After graduating from the Royal Military Academy, Brussels, he joined the Belgian Armed Forces, 2nd Guides armor regiment in Germany. He subsequently served as a military intelligence analyst at the Belgian Ministry of Defence and attended specialized training in the UK, US and Sweden. Between 1994 and 1999, he worked during a total of two years as a military information/intelligence officer in the UNPROFOR/UNPF (Zagreb, Croatia), UNTAES (Vukovar, Croatia) and SFOR headquarters (Sarajevo, BiH). From 2001 to 2009 he worked at the Office of the Prosecutor (OTP) at the ICTY as an Intelligence Analyst (Military), where he conducted in depth research and analysis in support of investigations and prosecutions of violations of international humanitarian law during the conflict in the former Yugoslavia, with particular emphasis on de jure and de facto (para) military command, control and communication structures. He testified in seven trials as a military expert witness called by the Prosecution on these matters. He had given several lectures on the role of (military) intelligence in the investigation and prosecution of violations of the law of 
armed conflict, and on intelligence in peace support operations.

Paper is published in: Vol. 13 No. 4, 2012.

The Honorable John Train, has received part-time appointments from Presidents Reagan, Bush and Clinton. He founded Train, Smith Investments Counsel in New York, and writes a column in London's Financial Times. He is the Senior Contributing Editor for Strategic Review.

Paper is published in: Vol. 1 No. 1, 2000.

Darko Trifunović, MSL, Ph.D. Senior Research Fellow and representative for Serbia and Montenegro of the International Strategic Studies Association (ISSA), Defense \& Foreign Affairs Publications, and the Global Information System (GIS). Dr Darko Trifunovic is a research fellow and lecturer at the Faculty of Security Studies at the University of Belgrade, a specialist in CounterTerrorism, National and International Security Studies. He has been elected to the position of a visiting professor at the Fudan University in China, Center for American Studies as well as research fellow of the Shanghai Institute of European Studies. Dr Darko Trifunovic is Senior Advisor at the RIEAS Research Institute for European and American Studies as well as member of Advisory Board of the Institute of Transnational Studies. $\mathrm{He}$ is former First Secretary of the Foreign Service of Bosnia and Herzegovina at the UN, Adviser to the State Secretary for War Crimes of Republic of Srpska for Terrorism and Violence and he was (in 2005) Adviser to the Minister of Police of the Republic of Srpska, Bosnia and Herzegovina. The Shanghai Center for International Studies 
appointed Dr. Darko Trifunovic as the first foreign expert for the Olympic Games (2008) security preparation in China. He was engaged in World Expo Security preparation 2010, Shanghai, Chaina. Dr. Darko Trifunovic is one of the founding members of ICTAC International Counter Terrorism Academic Community.

Paper is published in: Vol. 17 No. 1-2, 2016.

Dr. sc. Franjo Tuđman (b. 1922, Veliko Trgovišće, Croatia; †1999, Zagreb). Historian and statesman. Croatian president (1990-1999). Member of the antifascist movement during the World War II. In 1961 leaves active military service as major general. As a university professor and manager of the Institute for the History of the Labour Movement he comes into conflict with the communist regime for his advocation of Croatian national rights and political democracy. Sentenced to two years in prison in 1971, and to three years in 1981 in political trials. In 1989 establishes the Croatian Democratic Union (HDZ) through which he formulates a political program for independant and suverign Croatian state. Having won the first free multiparty elections in 1990, becomes the first Croatian president. $\mathrm{He}$ is reelected in 1992 and 1997. Graduated from a senior military academy, and earned a doctor's degree in political sciences in 1965. Member of the Croatian Academy of Arts and Sciences from 1992. Author of numerous articles and several books: Rat protiv rata (War Against War) (1957), Stvaranje socijalističke Jugoslavije (The Establishment of the Socialist Yugoslavia) (1960), Okupacija i revolucija (Occupation and Revolution) (1963), Uzroci krize monarhističke Jugoslavije od ujedinjenja 1918. do sloma 
1941. (Causes of the crisis in the Yugoslav monarchy; doctoral disseration) (1965), Velike ideje i mali narodi (Great Ideas and Small Nations) (1969), Nacionalno pitanje u suvremenoj Evropi (The National Issue in Modern Europe) (1981), Bespuća povijesne zbiljnosti. Rasprava o povijesti i filozofiji zlosilja (Horrors of War. An Essay on the History and Philosophy of Violence) (1989), Hrvatska u monarhističkoj Jugoslaviji 1918 - 1941 (Croatia in the Yugoslav Monarchy) (1993), S vjerom u samostalnu Hrvatsku (Believing in Croatia's Independence) (1995).

Paper is published in: Vol. 1 No. 3-4, 2000.

Prof. dr. sc. Miroslav Tudjman (b. 1946, Belgrade). Professor of information theory at the Philosophical Faculty of the University of Zagreb. Deputy Director of the Office for National Security (UNS) and the Director of the Croatian Intelligence Service (HIS) from 1993 to 1998, and from 1999 to 2000. Contributed to various scientific projects, published four books and over a hundred articles in scientific journals; editor of a dozen miscellaneous works. Active in research, both in the field of information theory and national security and intelligence.

Papers are published in: Vol. 1 No. 2, 2000; Vol. 1 No. 3-4, 2000; Vol. 2 No. 1-2, 2001; Vol. 9 No. 1-2, 2008; Vol. 10 No. 3-4, 2009; Vol. 14 No. 1, 2000; Vol. 14 No. 2, 2000; Vol. 16 No. 1 , 2015; Vol. 16 No. 2-3, 2015; Vol. 17 No. 3, 2016; Vol. 18 No. 3, 2017; Vol. 19 No. 3, 2018.

Prof. dr. sc. Giliam de Valk, published his PhD on the quality intelligence analyses have to meet, in 2005 . He 
is specialized in the methodology of security and intelligence analysis. He has worked at the University of Amsterdam, the University of Utrecht, and the Netherlands Defense Academy where he coordinated and lectured a minor on intelligence studies. At the moment he is an assistant professor at the Institute for Security and Global Affairs, Leiden University.

Paper is published in: Vol. 19 No. 1-2, 2018.

Dr. sc. Imre Varga, (b. 1958, Miskolc, Hungary) graduated from the Moscow State Institute of Foreign Affairs (1982); PhD studies at the "Miklós Zrínyi" University of National Defense (1998). Began his career in 1982 as a junior diplomat at the Ministry of Foreign Affairs. From 1985 to 1991, served in Belgrade as an attaché, third, and second secretary in the Hungarian Embassy. From 1991 to 1994, desk officer, head of the unit of the Fourth Department (Southeast Europe), Ministry of Foreign Affairs. In 1994, appointed Deputy Head of Mission at the Hungarian Embassy, Zagreb. From 1999 on, head of a unit in the Department of EU Coordination, State Secretariat for Integration, Ministry of Foreign Affairs. He is married, with three sons.

Paper is published in: Vol. 1 No. 2, 2000.

Miodrag Vlahović, born November 15, 1961. Graduated 1986 at the Podgorica Law Faculty. Lawyer. Co-owner \& consulting manager of Media Consult Inc. (one of the first private consulting agencies in Montenegro), from 1990. Main social/political activities: 1991- 92 founder and one of the leaders of Citizens Committee for Peace (Montenegrin Anti-War Movement); 1992-94 MP (Montenegrin Parliament); Member 
of Parliamentary Committee for internatinal relations; Committee for political systems; Committee for legal and administrative matters; 1992-93 Liberal Party of Montenegro, international secretary; 1991-93 columnist in independent weekly «Monitor», with over fifty articles; 1992-93 columnist in «Liberal», party paper; 1998 founder-member of CEDEM Montenegrin Center for Democracy \& Human Rights; 1999 director of CeRS, Center for Regional and Security Studies. Languages: English \& Italian.

Paper is published in: Vol. 2 No. 1-2, 2001.

Dr. sc. Radovan Vukadinović, is a professor of international political relations and director of post-graduate studies in international relations in the Department of Political Science, University of Zagreb. He has lectured at Columbia University, George Mason University and, since 1985, has been a visiting professor at Florida State University. He is the author of numerous books in the area of international relations, which have been published at home and abroad. He is the president of the Croatian Society of International Studies and the Atlantic Council of Croatia, and is also a member of several international organizations.

Paper is published in: Vol. 2 No. 1-2, 2001.

Hrvoje Vuković, univ. spec. pol., rođen je 1982. u Zagrebu. Kao mlađi profesionalni diplomat radi na Diplomatskoj akademiji MVEP RH. Završio je Filozofiju i religijsku kulturu na Filozofskom fakultetu Družbe Isusove u Zagrebu (2008.); jednogodišnji stručni diplomatski studij (2010.) na Diplomatskoj akademiji MVEP $\mathrm{RH}$ i 
poslijediplomski specijalistički studij Sigurnosna politika RH na Fakultetu političkih znanosti u Zagrebu (2012.) s temom „Kibernetsko ratovanje i kibernetski terorizam - sustavi borbe protiv kibernetskih prijetnji“ - stekavši akademski naziv sveučilišnog specijaliste za nacionalnu sigurnost. Sudionik je brojnih međunarodnih konferencija, seminara i radnih stolova na temu međunarodnih odnosa, diplomacije, te nacionalne i međunarodne sigurnosti. Član je Udruge hrvatskih diplomata.

Paper is published in: Vol. 13 No. 3, 2012.

Col. Gen. Markus Wolf, (b. January 19, 1923 in Hechingen, South-Wurttemberg, Germany) emigrated with his parents to Switzerland and France (1933) and then to the Soviet Union (1934). Received Soviet citizenship in 1936. Attended high school in Moscow (1937-1940) and studied at the Institute for Flight Construction in Alma Ata (1940-1942); 1942-1943 attended the Communist Internationale School in Kuschnarenkowo; Editor, Speaker and Commentator for the German National Radio, Institute 205, in Moscow (1943-1945). In 1945 returned to Germany; 1945-1949 worked with the Berlin Radio (under the pseudonym Michael Storm); 1949 first counselor to the Mission of the GDR in Moscow; 1950-1951 renounced Soviet citizenship. 1951 employed in the Foreign Intelligence Department (Außenpolitischen Nachrichtendienst - APN), and in November, 1952, became director of APN; after APN was incorporated into the Ministry of State Security of the GDR, became director of new APN (1953). From 1956 on, delegated Minister of State Security and Head of the Foreign Intelligence Department, rank of Major General. 1980 promoted to Colonel 
General. Recipient of numerous high civil and military decorations and awards. 1983 requested retirement; left active duty in 1986 and became active as a writer. Summer of 1989, indictment issued in the Federal Republic of Germany against Wolf. Returned to Germany September 24, 1991 and was arrested at the German border and imprisoned. On October 4, 1991 released on bail. 1993 sentenced for treason to six years imprisonment (suspended); 1997 sentenced to two years probation and monetary fine. Publications: Die Troika, Berlin 1989; In My Own Service: Confessions and Insights, Munich 1991. Secrets of the Russian Cuisine, Hamburg 1995. Spy Chief in the Secret War: Reminiscences, Munich, 1997 (and in 15 other countries); The Art of Deception, Berlin 1998. Wolf is married and lives in Berlin.

Paper is published in: Vol. 1 No. 2, 2000.

Dr. sc. Božo Žepić, rođen je 1938. godine u Živinicama $(\mathrm{BiH})$, gdje je završio osnovnu i srednju školu. Studirao je i 1968. diplomirao sociologiju pri Fakultetu političkih znanosti u Sarajevu. Poslijediplomske studije i akademska zvanja speci-jaliste i magistra stekao je na pravnom fakultetu iz oblasti radnog i socijalnog prava. Doktorirao je na Pravnom fakulte $\neg$ tu u Banja Luci obranom disertacije na temu Društvenopravni položaj invalida rada. Redoviti je profesor Pravnog fakulteta Sveučilišta u Mostaru. $\mathrm{Na}$ više sveučilišta i fakulteta predavao je opću i industrijsku sociologiju, radno i socijalno pravo te suvremene političke sustave. Sudjelovao je u izvođenju poslijediplomske nastave na pravnim fakultetima u Mostaru, Splitu i Banja Luci, te na Filozofskom fakultetu u Zagrebu. Objavio je oko 
110 znanstvenih i stručnih radova iz opće i industrijske sociologije, radnog i socijalnog prava te suvremenih političk ih sustava. Od toga pet knjiga u deset izdanja. Najvažnija su mu djela udžbenici za studente: Osnovi sociologije, Radno i socijalno pravo te Suvremeni politički sustavi. U dva izdanja objavljena mu je i knjiga Društveno-pravni položaj invalida rada. Posebnu pozornost znanstvene, stručne i političke javnosti izazvala je njegova knjiga Enigma Bosna i Hercegovina.

Papers are published in: Vol. 6 No. 1-2, 2005; Vol. 6 No. 3-4, 2005.

Prof. dr. sc. Vilko Žiljak, is a Full Professor at the University of Zagreb (Croatia), Faculty of Graphic Engineering. He received Ph.D. degree from the Zagreb Faculty of Electronic Engineering, Zagreb, Croatia, 1989, in the scientific field of Computer Science. His research interests include: Computer Science and simulation science models, relations between graphical and technical development (macro and micro simulation models), and classical and modern graphical and technical simulation systems, especially in field of mathematical modelling and simulation analysis. He has published more than 60 papers and 2 books about computer simulation and modelling.

Paper is published in: Vol. 3 No. 1-2, 2002.

Prof. dr. sc. Dražen Živić, (1968.) rođen je u Vukovaru. Diplomirao je 1993. godine na Geografskom odsjeku Prirodoslovno-matematičkog fakulteta Sveučilišta u Zagrebu. Na istom je fakultetu magistrirao 1998. i doktorirao 2000. godine. Kao znanstveni savjetnik radi na Institutu društvenih znanosti Ivo Pilar. Posebno se bavi 
istraživanjima povezanima $s$ demografijom Hrvatske, demografijom malih područja, demografijom braka i obitelji, demografskim posljedicama rata te etnodemografijom. Bio je voditelj projekta „Demografski gubici i posljedice Domovinskog rata" (2002. - 2006.). Od 2008. godine voditelj je projekta „Demografski aspekti urbano-ruralne polarizacije Hrvatske“. Voditelj je i Područnoga centra Instituta Ivo Pilar u Vukovaru. Bio je profesor na Odsjeku sociologije Hrvatskih studija Sveučilišta u Zagrebu (2003. - 2012.). Predaje i na Studiju povijesti na Hrvatskom katoličkom sveučilištu, na Diplomatskoj akademiji Ministarstva vanjskih poslova i europskih integracija te na Specijalističkom poslijediplomskom studiju Pastoralne teologije na Katoličkom bogoslovnom fakultetu u Đakovu. Dobitnik je Državne nagrade za znanost na području društvenih znanosti za znanstvene novake (2001.). Objavio je stotinjak znanstvenih i stručnih radova u međunarodno referiranim časopisima, zbornicima radova i knjigama. Sudjelovao je na pedesetak hrvatskih i međunarodnih znanstvenih skupova. Član je više strukovnih udruga te Vijeća za život i obitelj Hrvatske biskupske konferencije.

Paper is published in: Vol. 12 No. 3, 2011. 